\title{
Heterogeneous chemistry: a mechanism missing in current models to explain secondary inorganic aerosol formation during the January 2013 haze episode in North China
}

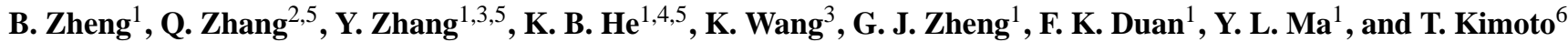 \\ ${ }^{1}$ State Key Joint Laboratory of Environment Simulation and Pollution Control, School of Environment, \\ Tsinghua University, Beijing, China \\ ${ }^{2}$ Ministry of Education Key Laboratory for Earth System Modeling, Center for Earth System Science, \\ Tsinghua University, Beijing, China \\ ${ }^{3}$ Department of Marine, Earth and Atmospheric Sciences, North Carolina State University, Raleigh, North Carolina, USA \\ ${ }^{4}$ State Environmental Protection Key Laboratory of Sources and Control of Air Pollution Complex,Beijing 100084, China \\ ${ }^{5}$ Collaborative Innovation Center for Regional Environmental Quality, Beijing 100084, China \\ ${ }^{6}$ Kimoto Electric Co., Ltd, 3-1 Funahashi-cho Tennoji-ku Osaka, 543-0024, Japan
}

Correspondence to: Q. Zhang (qiangzhang@tsinghua.edu.cn) and K. B. He (hekb@tsinghua.edu.cn)

Received: 13 May 2014 - Published in Atmos. Chem. Phys. Discuss.: 25 June 2014

Revised: 19 January 2015 - Accepted: 19 January 2015 - Published: 25 February 2015

\begin{abstract}
Severe regional haze pollution events occurred in eastern and central China in January 2013, which had adverse effects on the environment and public health. Extremely high levels of particulate matter with aerodynamic diameter of $2.5 \mu \mathrm{m}$ or less $\left(\mathrm{PM}_{2.5}\right)$ with dominant components of sulfate and nitrate are responsible for the haze pollution. Although heterogeneous chemistry is thought to play an important role in the production of sulfate and nitrate during haze episodes, few studies have comprehensively evaluated the effect of heterogeneous chemistry on haze formation in China by using the 3-D models due to of a lack of treatments for heterogeneous reactions in most climate and chemical transport models. In this work, the WRF-CMAQ model with newly added heterogeneous reactions is applied to East Asia to evaluate the impacts of heterogeneous chemistry and the meteorological anomaly during January 2013 on regional haze formation. As the parameterization of heterogeneous reactions on different types of particles is not well established yet, we arbitrarily selected the uptake coefficients from reactions on dust particles and then conducted several sensitivity runs to find the value that can best match observations. The revised CMAQ with heterogeneous chemistry not only captures the magnitude and temporal variation of sulfate and nitrate, but also reproduces the enhancement of relative contribution of
\end{abstract}

sulfate and nitrate to $\mathrm{PM}_{2.5}$ mass from clean days to polluted haze days. These results indicate the significant role of heterogeneous chemistry in regional haze formation and improve the understanding of the haze formation mechanisms during the January 2013 episode.

\section{Introduction}

Regional haze pollution is an atmospheric phenomenon characterized by significant growth in the concentration of aerosol particles and sharp reduction of visibility. In addition to the adverse effects on visibility, haze pollution also affects the air quality, public health and climate. By scattering and absorbing solar radiation, aerosol particles suspended within haze can decrease the fluxes of solar radiation reaching the Earth's surface, significantly altering the Earth's energy budget and climate (Seinfeld et al., 2004; Mercado et al., 2009). Sulfate and nitrate aerosols can increase soil acidity through acid deposition, which has a negative impact on the ecosystem (Zhao et al., 2009). Because of their small sizes, aerosol particles can penetrate deeply into human lungs, causing respiratory diseases, decreased lung function, and increased risk of cancer and mortality (American Lung Association, 2006). 
Haze pollution in China is of significant concern because of its increased frequency of occurrence in recent years. The number of haze days has shown an increasing trend since the 1990s and visibility during the haze events has decreased rapidly (Zhao et al., 2011; Ding and Liu, 2014). Aerosol loadings during haze days can be extremely high with maximum hourly concentrations of particulate matter with aerodynamic diameter of $2.5 \mu \mathrm{m}$ or less $\left(\mathrm{PM}_{2.5}\right)$ of 200 $1000 \mathrm{\mu g} \mathrm{m}^{-3}$ (Sun et al., 2006; Wang et al., 2006, 2014b, c; Zhao et al., 2013b), which can reduce surface solar radiation by more than $20 \mathrm{~W} \mathrm{~m}^{-2}$ (Li et al., 2007).

Most parts of central and eastern China experienced a persistent episode of haze pollution during January 2013, which is one of the most severe air pollution episodes in China during the last decade (He et al., 2014; Wang et al., 2014c, d; Zhang et al., 2014a, b). Widespread haze clouds covered the entire North China Plain (NCP) (Yang et al., 2013) and the instantaneous concentration of $\mathrm{PM}_{2.5}$ within these clouds exceeded $1000 \mu \mathrm{g} \mathrm{m}^{-3}$ at some urban observational sites (Wang et al., 2014c). The characteristics and formation mechanisms of this haze event attract considerable attention from the scientific community.

High emission intensity, adverse meteorological conditions, and the formation of substantial amounts of secondary aerosols are generally regarded as the principal factors underlying the formation of the severe haze pollution in January 2013. Central and eastern China are the most important source regions of anthropogenic emissions in China (Zhang et al., 2009), which can provide sufficient precursors for haze formation. Adverse meteorological conditions in January 2013 conducive to haze formation include weak surface winds, low mixing layers, a thick temperature inversion layer and anomalous southerly winds in the middle and lower troposphere that transport large amounts of water vapor and pollutants (Wang et al., 2014c; Zhang et al., 2014b). Under weather conditions of high humidity and reduced advection and vertical mixing, large amounts of secondary aerosols (both organic and inorganic) can be generated. In particular, greater amounts of secondary inorganic aerosols comprising sulfate, nitrate and ammonium (SNA) were produced during the haze days of the January 2013 episode than during clean days. The contribution of sulfate and nitrate to $\mathrm{PM}_{2.5}$ increased from $10.3-13.4 \%$ and $6.6-14 \%$ in clean days to $25.1 \%$ and $17.5-20.6 \%$ in haze days, respectively (Zhang et al., 2014a; Quan et al., 2014). The total contribution of SNA reached about $60 \%$ during the most severe haze days from 12-15 January (Zhang et al., 2014a; Quan et al., 2014), which indicates that the significant production of SNA is a principal driving force that leads to the sharp increase in $\mathrm{PM}_{2.5}$ concentrations.

Many studies on aerosols have revealed that SNA are the most abundant component of $\mathrm{PM}_{2.5}$ during haze pollution events in China, and that the processes and evolution of haze pollution are characterized by the formation of substantial amounts of sulfate and nitrate (Sun et al., 2006; Wang et al.,
2006; Zhao et al., 2013b). The formation mechanisms are difficult to be explained by traditional gas-phase or aqueousphase chemistry (i.e., gas-phase oxidation by hydroxyl radical $(\mathrm{OH})$ and in-cloud oxidation by dissolved ozone $\left(\mathrm{O}_{3}\right)$ and hydrogen peroxide $\left.\left(\mathrm{H}_{2} \mathrm{O}_{2}\right)\right)$ given the adverse atmospheric conditions (i.e., low or even zero $\mathrm{O}_{3}$ concentrations, dim days with low solar radiations and few precipitating clouds) (Zhao et al., 2013b; Quan et al., 2014). Besides the gas-phase and aqueous-phase chemistry, heterogeneous chemistry is considered as alternative pathways of sulfate and nitrate formation in the atmosphere (Ravishankara, 1997). The ambient measurement has verified the existence of heterogeneous reactions associated with sulfur dioxide $\left(\mathrm{SO}_{2}\right)$, nitrogen pentoxide $\left(\mathrm{N}_{2} \mathrm{O}_{5}\right)$ and nitric acid $\left(\mathrm{HNO}_{3}\right)$ (Usher et al., 2003; Lammel and Leip, 2005; McNaughton et al., 2009; Chang et al., 2011). Field studies during haze days in China proposed that the large amount of sulfate and nitrate were more likely generated via heterogeneous chemistry than gas-phase and aqueous-phase chemistry (Wang et al., 2006; Li and Shao, 2009, 2010; Li et al., 2011; Wang et al., 2012c, 2014c; Zhao et al., 2013b). Modeling studies have used 0-D to 3-D air quality models to research on the role of heterogeneous reactions in sulfate and nitrate formation on the surface of mineral particles (Zhang et al., 1994; Dentener et al., 1996; Zhang and Carmichael, 1999; Wang et al., 2012a). However, few studies have comprehensively evaluated the effect of heterogeneous chemistry on haze formation in China by using the 3-D models because of a lack of treatments for heterogeneous reactions in most climate and chemical transport models.

In this work, we use the CMAQ model to investigate the impact of heterogeneous chemistry on the severe regional haze formation in January 2013. The officially released version of CMAQ (hereafter the original CMAQ) and revised CMAQ with updated treatments for heterogeneous chemistry by adding a number of reactions (hereafter the revised CMAQ) are applied to simulate the January 2013 severe regional haze pollution episode over East Asia. Our objectives are to improve the model's capability in reproducing the observed high PM concentrations and provide better understanding of the effects of heterogeneous reactions on the production of sulfate and nitrate during the haze event.

\section{Model description and methodology}

In this work, the Weather Research and Forecasting (WRF) model v3.5.1 (http://www.wrf-model.org/) and CMAQ v5.0.1 (http://www.cmascenter.org/cmaq/) are applied to simulate the severe haze episode in January 2013 over East Asia. WRF is a new-generation mesoscale numerical weather prediction system designed to serve a wide range of meteorological applications from meters to thousands of kilometers (http://www.wrf-model.org/). WRF v3.5.1 is the most recent major WRF release in September 2013 and is used 
to generate meteorological fields to drive CMAQ. CMAQ is a 3-D Eulerian atmospheric chemistry and transport modeling system that simulates multi-pollutants throughout the troposphere across spatial scales ranging from local to hemispheric. CMAQ v5.0.1 is the most up-to-date release in July 2012. It contains the updated carbon bond gas-phase mechanism with new toluene chemistry (Whitten et al., 2010), a new aerosol module (AERO6) and ISORROPIA v2.1 inorganic chemistry (Fountoukis and Nenes, 2007). The existing formation mechanisms for SNA included in the original CMAQ and new heterogeneous reactions added in the revised CMAQ that form additional SNA are described below.

\subsection{The formation mechanisms of SNA in the original CMAQ}

Table 1 summarizes major mechanisms for sulfate and nitrate formation currently treated in the original CMAQ v5.0.1 (R1-R15) in a highly simplified manner. In the gas phase (R1-R6), sulfuric acid $\left(\mathrm{H}_{2} \mathrm{SO}_{4}\right)$ and $\mathrm{HNO}_{3}$ are generated mainly through the oxidation of $\mathrm{SO}_{2}$ and nitrogen oxide $\left(\mathrm{NO}_{x}\right)$ by $\mathrm{OH}$. Additional $\mathrm{HNO}_{3}$ can be formed through subsequent reactions involving reactive nitrogen species such as nitrogen trioxide $\left(\mathrm{NO}_{3}\right), \mathrm{N}_{2} \mathrm{O}_{5}$, and NTR and $\mathrm{OH}$, hydroperoxyl radical $\left(\mathrm{HO}_{2}\right)$, and $\mathrm{H}_{2} \mathrm{O}$ as well as the nighttime oxidation reaction of volatile organic compounds (VOCs) by $\mathrm{NO}_{3} . \mathrm{H}_{2} \mathrm{SO}_{4}$ and $\mathrm{HNO}_{3}$ can condense on the surface of preexisting aerosol, forming sulfate $\left(\mathrm{SO}_{4}^{2-}\right)$ and nitrate $\left(\mathrm{NO}_{3}^{-}\right)$. For in-cloud chemistry (R7-R13), the original CMAQ includes the dissolution equilibria of $\mathrm{SO}_{2}, \mathrm{H}_{2} \mathrm{SO}_{4}$, ammonia $\left(\mathrm{NH}_{3}\right), \mathrm{NO}_{\mathrm{x}}, \mathrm{NO}_{3}, \mathrm{~N}_{2} \mathrm{O}_{5}$, nitrous acid $\left(\mathrm{HNO}_{2}\right), \mathrm{HNO}_{3}$, peroxynitric acid $\left(\mathrm{HNO}_{4}\right)$, and several oxidants such as $\mathrm{OH}$, $\mathrm{H}_{2} \mathrm{O}_{2}$, and $\mathrm{O}_{3}$, the dissociation equilibria of $\mathrm{SO}_{2}$, bisulfite $\left(\mathrm{HSO}_{3}^{-}\right), \mathrm{HNO}_{2}, \mathrm{HNO}_{3}$, and $\mathrm{NH}_{3} \cdot \mathrm{H}_{2} \mathrm{O}$, and five aqueousphase kinetic reactions to produce $\mathrm{S}$ (VI) through the oxidation of $\mathrm{S}(\mathrm{IV})$ (dissolved $\mathrm{SO}_{2}, \mathrm{HSO}_{3}^{-}$and sulfite $\left(\mathrm{SO}_{3}^{2-}\right)$ ) by $\mathrm{H}_{2} \mathrm{O}_{2}$, methylhydroperoxide (MHP), peroxyacetic acid (PAA), $\mathrm{O}_{3}$, and oxygen $\left(\mathrm{O}_{2}\right)$ catalyzed by ferric iron $\left(\mathrm{Fe}^{3+}\right)$ and manganese ion $\left(\mathrm{Mn}^{2+}\right)$. Once clouds dissipate, $\mathrm{SO}_{4}^{2-}$ formed in the aqueous phase becomes part of aerosol. The original CMAQ only includes two heterogeneous reactions (R14-R15) to produce $\mathrm{HNO}_{3}$, one involving $\mathrm{N}_{2} \mathrm{O}_{5}$ and $\mathrm{H}_{2} \mathrm{O}$ and the other involving nitrogen dioxide $\left(\mathrm{NO}_{2}\right)$ and $\mathrm{H}_{2} \mathrm{O}$. The mechanism of heterogeneous chemistry is much more complex than the homogeneous gas- and aqueous-phase mechanisms. It involves many processes including water condensation onto the particle surfaces, adsorption and accommodation of gases into the liquid-gas interface, diffusion, and surface reactions (Reid and Sayer, 2003). Heterogeneous reaction rates are dependent on relative humidity (RH) (Dentener et al., 1996; Henson et al., 1996; Stutz et al., 2004) because of the significant role of the water film on the aerosol surface in the gas uptake. The formation of ammonium $\left(\mathrm{NH}_{4}^{+}\right)$is closely related to that of $\mathrm{SO}_{4}^{2-}$ and $\mathrm{NO}_{3}^{-}$,

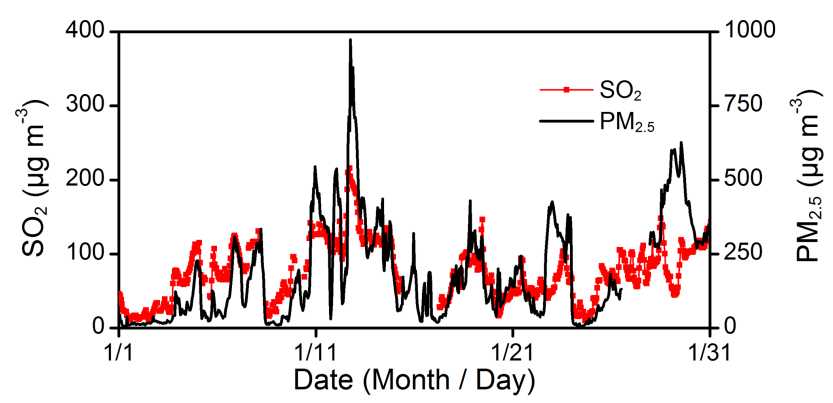

Figure 1. Observed concentrations of $\mathrm{SO}_{2}$ and $\mathrm{PM}_{2.5}$ during January 2013 in Beijing.

as it results from the neutralization of $\mathrm{SO}_{4}^{2-}$ and $\mathrm{NO}_{3}^{-}$by dissolved $\mathrm{NH}_{3}$ in the particulate phase through aerosol equilibrium treated in ISORROPIA II of Fountoukis and Nenes (2007).

\subsection{Missing heterogeneous reactions and their implementation into original CMAQ}

Heterogeneous chemistry might have played a significant role in the January 2013 haze episode for three reasons. First, the total amount of $\mathrm{SO}_{4}^{2-}$ formed through gas- and aqueousphase chemistry is too low to explain the observed abrupt increases in the concentrations of $\mathrm{SO}_{4}^{2-}$ by $70-130 \mu \mathrm{g} \mathrm{m}^{-3}$ within a few hours during the haze episode. The observed concentrations of $\mathrm{SO}_{2}$ are in the range of $10-216 \mu \mathrm{g} \mathrm{m}^{-3}$ (Fig. 1). The gas-phase oxidation of $\mathrm{SO}_{2}$ by $\mathrm{OH}$ radicals can convert $\mathrm{SO}_{2}$ to $\mathrm{H}_{2} \mathrm{SO}_{4}$ at a maximum rate of $2 \% \mathrm{~h}^{-1}$ under sunny conditions, leading to $0.2-5.5 \mu \mathrm{g} \mathrm{m}^{-3} \mathrm{~h}^{-1} \mathrm{H}_{2} \mathrm{SO}_{4}$ (which is equivalent to $0.2-5.4 \mu \mathrm{g} \mathrm{m}^{-3} \mathrm{~h}^{-1} \mathrm{SO}_{4}^{2-}$ ). Aqueousphase chemistry as shown in Table 1 can enhance $\mathrm{SO}_{4}^{2-}$ formation in precipitating clouds, which did not occur frequently during the episode. Only two precipitations are recorded in central China, on 20-21 and 30-31 January, which contribute $92 \%$ of the total precipitation in January (data derived from http://cdc.cma.gov.cn). Meanwhile the weak photochemical activity during dim haze days, characterized by extremely low or even zero $\mathrm{O}_{3}$ concentrations $(\mathrm{He}$ et al., 2014; Wang et al., 2014c), does not support that gasand aqueous-phase chemistry are dominant pathways for sulfate and nitrate production. As shown in Table 1, the original CMAQ only includes two heterogeneous reactions to produce $\mathrm{HNO}_{3}$ and does not include any heterogeneous reactions to produce $\mathrm{SO}_{4}^{2-}$. The original model evaluation against ground-based measurements (as shown in Sect. 4.2.1) shows significant underpredictions of SNA (e.g., normalized mean biases (NMBs) of -40 to $-60 \%$ ). These data analysis and modeling results indicate that the heterogeneous chemistry probably have played a significant role to produce high SNA during the haze pollution. Second, there exist strong correlations between RH and sulfur and nitrogen oxidation ratios (SOR and NOR) during haze in January 2013 (Sun et al., 
Table 1. Main reactions contributing to sulfate and nitrate production in original CMAQ and heterogeneous reactions newly added in revised CMAQ.

\begin{tabular}{|c|c|c|c|}
\hline Type & Reaction \#. & Reaction & Contributions to $\mathrm{PM}_{2.5}$ \\
\hline \multicolumn{4}{|l|}{ original $C M A Q$} \\
\hline $\begin{array}{l}\text { Gas-phase chemistry } \\
\text { (All species in gas phase) }\end{array}$ & $\begin{array}{l}\text { R1 } \\
\text { R2 } \\
\text { R3 } \\
\text { R4 } \\
\text { R5 } \\
\text { R6 }\end{array}$ & $\begin{array}{l}\mathrm{SO}_{2}+\mathrm{OH}+\mathrm{H}_{2} \mathrm{O}+\mathrm{O}_{2} \rightarrow \mathrm{H}_{2} \mathrm{SO}_{4}+\mathrm{HO}_{2} \\
\mathrm{NO}_{2}+\mathrm{OH} \rightarrow \mathrm{HNO}_{3} \\
\mathrm{~N}_{2} \mathrm{O}_{5}+\mathrm{H}_{2} \mathrm{O} \rightarrow 2 \mathrm{HNO}_{3} \\
\mathrm{NO}_{3}+\mathrm{HO}_{2} \rightarrow \mathrm{HNO}_{3}+\mathrm{O}_{2} \\
\mathrm{NTR}^{a}+\mathrm{OH} \rightarrow \mathrm{HNO}_{3} \\
\mathrm{NO}_{3}+\mathrm{VOCs}^{\mathrm{b}} \rightarrow \mathrm{HNO}_{3}\end{array}$ & $\begin{array}{l}\text { Sulfate } \\
\text { Nitrate } \\
\text { Nitrate } \\
\text { Nitrate } \\
\text { Nitrate } \\
\text { Nitrate }\end{array}$ \\
\hline $\begin{array}{l}\text { Aqueous-phase kinetic chem- } \\
\text { istry }\end{array}$ & $\mathrm{R} 7$ & $\mathrm{HSO}_{3}^{-}+\mathrm{H}_{2} \mathrm{O}_{2} \rightarrow \mathrm{SO}_{4}^{2-}+\mathrm{H}^{+}+\mathrm{H}_{2} \mathrm{O}$ & Sulfate \\
\hline \multirow[t]{6}{*}{ (All species in aqueous phase) } & $\mathrm{R} 8$ & $\mathrm{HSO}_{3}^{-}+\mathrm{MHP}^{\mathrm{c}} \rightarrow \mathrm{SO}_{4}^{2-}+\mathrm{H}^{+}$ & Sulfate \\
\hline & R9 & $\mathrm{HSO}_{3}^{-}+\mathrm{PAA}^{\mathrm{d}} \rightarrow \mathrm{SO}_{4}^{2-}+\mathrm{H}^{+}$ & Sulfate \\
\hline & $\mathrm{R} 10$ & $\mathrm{SO}_{2}+\mathrm{O}_{3}+\mathrm{H}_{2} \mathrm{O} \rightarrow \mathrm{SO}_{4}^{2-}+2 \mathrm{H}^{+}+\mathrm{O}_{2}$ & Sulfate \\
\hline & R11 & $\mathrm{HSO}_{3}^{-}+\mathrm{O}_{3} \rightarrow \mathrm{SO}_{4}^{2-}+\mathrm{H}^{+}+\mathrm{O}_{2}$ & Sulfate \\
\hline & $\mathrm{R} 12$ & $\mathrm{SO}_{3}^{2-}+\mathrm{O}_{3} \rightarrow \mathrm{SO}_{4}^{2-}+\mathrm{O}_{2}$ & Sulfate \\
\hline & $\mathrm{R} 13$ & $\mathrm{SO}_{2}+\mathrm{H}_{2} \mathrm{O}+0.5 \mathrm{O}_{2}+\mathrm{Fe}(\mathrm{III}) / \mathrm{Mn}(\mathrm{II}) \rightarrow \mathrm{SO}_{4}^{2-}+2 \mathrm{H}^{+}$ & Sulfate \\
\hline Heterogeneous & R14 & $\mathrm{N}_{2} \mathrm{O}_{5}(\mathrm{~g})+\mathrm{H}_{2} \mathrm{O}(\mathrm{aq}) \rightarrow 2 \mathrm{HNO}_{3}(\mathrm{aq})$ & Nitrate \\
\hline chemistry $\mathrm{e}$ & $\mathrm{R} 15$ & $2 \mathrm{NO}_{2}(\mathrm{~g})+\mathrm{H}_{2} \mathrm{O}(\mathrm{aq}) \rightarrow \mathrm{HONO}(\mathrm{aq})+\mathrm{HNO}_{3}(\mathrm{aq})$ & Nitrate \\
\hline \multicolumn{4}{|l|}{ revised $C M A Q$} \\
\hline \multirow{9}{*}{$\begin{array}{l}\text { Newly added } \\
\text { heterogeneous chemistry }\end{array}$} & $\mathrm{R} 16$ & $\mathrm{H}_{2} \mathrm{O}_{2}(\mathrm{~g})+$ Aerosol $\rightarrow$ Products & Affect R7 \\
\hline & $\mathrm{R} 17$ & $\mathrm{HNO}_{3}(\mathrm{~g})+$ Aerosol $\rightarrow 0.5 \mathrm{NO}_{3}^{-}+0.5 \mathrm{NO}_{\mathrm{x}}(\mathrm{g})$ & Renoxification \\
\hline & $\mathrm{R} 18$ & $\mathrm{HO}_{2}(\mathrm{~g})+\mathrm{Fe}(\mathrm{II}) \rightarrow \mathrm{Fe}(\mathrm{III})+\mathrm{H}_{2} \mathrm{O}_{2}$ & Affect R4 and R7 \\
\hline & R19 & $\mathrm{N}_{2} \mathrm{O}_{5}(\mathrm{~g})+$ Aerosol $\rightarrow 2 \mathrm{NO}_{3}^{-}$ & Nitrate \\
\hline & $\mathrm{R} 20$ & $\mathrm{NO}_{2}(\mathrm{~g})+$ Aerosol $\rightarrow \mathrm{NO}_{3}^{-}$ & Nitrate \\
\hline & $\mathrm{R} 21$ & $\mathrm{NO}_{3}(\mathrm{~g})+$ Aerosol $\rightarrow \mathrm{NO}_{3}^{-}$ & Nitrate \\
\hline & $\mathrm{R} 22$ & $\mathrm{O}_{3}(\mathrm{~g})+$ Aerosol $\rightarrow$ Products & Affect R10-R12 \\
\hline & $\mathrm{R} 23$ & $\mathrm{OH}(\mathrm{g})+$ Aerosol $\rightarrow$ Products & Affect R1-R2, R5 \\
\hline & $\mathrm{R} 24$ & $\mathrm{SO}_{2}(\mathrm{~g})+$ Aerosol $\rightarrow \mathrm{SO}_{4}^{2-}$ & Sulfate \\
\hline
\end{tabular}

a NTR: organic nitrate.

b VOCs: formaldehyde, acetaldehyde, propionaldehyde and higher aldehydes, cresol and higher molecular weight phenols, nitro cresol, aromatic ring open products, and isoprene oxidation products.

c MHP: methylhydroperoxide.

d PAA: peroxyacetic acid.

e R14 and R15 were removed after R16-R24 were added into the model.

2014; Wang et al., 2014c; Zheng et al., 2014b), which resemble the RH-dependence of heterogeneous chemistry. Third, transmission electron microscopy studies have shown that the particles sampled during haze days in the NCP are mostly combined with obvious coatings containing significant sulfur and nitrogen elements, probably generated via some reactions on the particle surfaces ( $\mathrm{Li}$ and Shao, 2009, 2010; Li et al., 2011). This suggests that surface reactions, probably caused by heterogeneous chemistry, play a significant role in haze formation. Based on the above three reasons, heterogeneous chemistry is regarded as the most important missing reaction pathway and nine new heterogeneous reactions (R16-R24) were therefore incorporated into CMAQ to improve its capability in reproducing the high SNA concentrations observed during the haze episode through increasing sulfate and nitrate formation. Simulations from the original and the revised CMAQ are compared to study the role of heterogeneous chemistry in producing sulfate and nitrate during this haze episode, as presented in Sects. 4.2 and 4.3.

As shown in Table 1, following the work of Wang et al. (2012a), nine heterogeneous reactions involving $\mathrm{H}_{2} \mathrm{O}_{2}$, $\mathrm{HNO}_{3}, \mathrm{HO}_{2}, \mathrm{~N}_{2} \mathrm{O}_{5}, \mathrm{NO}_{2}, \mathrm{NO}_{3}, \mathrm{O}_{3}, \mathrm{OH}$ and $\mathrm{SO}_{2}$ (R16$\mathrm{R} 24)$ have been incorporated into the original CMAQ. These reactions are assumed to occur on the surface of aerosols. Heterogeneous chemistry is commonly parameterized using a pseudo-first-order rate constant and is assumed to be irreversible (Zhang and Carmichael, 1999; Jacob, 2000). The rate constant $k\left(\mathrm{~s}^{-1}\right)$ for heterogeneous loss of gaseous pol- 
lutants is determined by (Jacob, 2000; Wang et al., 2012a)

$k_{i}=\left(\frac{d_{\mathrm{p}}}{2 D_{i}}+\frac{4}{v_{i} \gamma_{i}}\right)^{-1} S_{\mathrm{p}}$

where $i$ represents the reactant for heterogeneous reactions, $d_{\mathrm{p}}$ is the effective diameter of the particles (m), $D_{i}$ is the gasphase molecular diffusion coefficient for reactant $i\left(\mathrm{~m}^{2} \mathrm{~s}^{-1}\right)$, $v_{i}$ is the mean molecular speed of reactant $i$ in the gas phase, $\gamma_{i}$ is the uptake coefficient for reactant $i$ (dimensionless), and $S_{\mathrm{p}}$ is the aerosol surface area per unit volume of air $\left(\mathrm{m}^{2} \mathrm{~m}^{-3}\right)$. The parameters $d_{\mathrm{p}}, D_{i}, v_{i}$, and $S_{\mathrm{p}}$ are calculated in CMAQ, and the parameter $\gamma_{i}$ is determined for different reactants based on laboratory measurements reported in the literature, as presented below.

The values of $\gamma$ for different gaseous pollutants may vary by several orders of magnitude, because of different surface properties, particle compositions, temperature, $\mathrm{RH}$, and laboratory conditions. For a specific combination of particle and gaseous pollutants, the value of $\gamma$ is highly dependent on $\mathrm{RH}$ and increases rapidly as a function of RH (Dentener et al., 1996; Henson et al., 1996; Stutz et al., 2004). For example, Mogili et al. (2006) found that the $\gamma$ of $\mathrm{N}_{2} \mathrm{O}_{5}$ increased by a factor of 4 as RH increased in an environmental aerosol chamber. Liu et al. (2008) reported that the $\gamma$ of $\mathrm{HNO}_{3}$ on calcium carbonate was enhanced in laboratory experiments by a factor of 15 over a wide range of RHs (from $20-80 \%$ ). Enhanced $\gamma$ of $\mathrm{HNO}_{3}$ with increasing $\mathrm{RH}$ have also been reported on many types of particles including oxides, clay and dust. Considering the significant effect of $\mathrm{RH}$ on $\gamma$, some modeling studies used RH-dependent $\gamma$ (Song and Carmichael, 2001; Wei, 2010). For example, Song and Carmichael (2001) used a value of $\gamma$ of 0.005 for $\mathrm{SO}_{2}$ when the RH was lower than $50 \%$ and of 0.05 when RH was higher than $50 \%$.

The $\gamma$ for heterogeneous reactions used in this work are determined mainly based on the work of Wang et al. (2012a), which used lower and upper limits to represent a range of $\gamma$ values reported in the laboratory measurement. On the basis of the lower and upper limits, we then use a piecewise function to represent the RH-dependence of $\gamma$. Field measurements during the January 2013 haze episode in Beijing indicate that the SOR and NOR are highly dependent on RH. They are relatively stable when RH is lower than $40-50 \%$ and rapidly increase when $\mathrm{RH}$ is higher. The $\mathrm{RH}$ value of $50 \%$ is close to the deliquescence point of particles for a mixture of organic compounds and ammonium sulfate (Peckhaus et al., 2012), which constitute about $80 \%$ of $\mathrm{PM}_{2.5}$ in China (Yang et al., 2011). In this work, we assume the value of $\gamma$ to be the lower limit for $\mathrm{RH} \leq 50 \%$ and that it increases linearly to the upper limit as $\mathrm{RH}$ increases to $\mathrm{RH}_{\max }$, which approximates the correlation between RH and $\gamma$. The $\gamma$ values of the reactions contributing to sulfate and nitrate (R19-
R21, R24) are calculated as the following equation:

$\gamma_{i}=\left\{\begin{array}{l}\gamma_{\text {low }}, \mathrm{RH} \in[0,50 \%] \\ \gamma_{\text {low }}+\left(\gamma_{\text {high }}-\gamma_{\text {low }}\right) /\left(\mathrm{RH}_{\max }-0.5\right) \\ \times(\mathrm{RH}-0.5), \mathrm{RH} \in\left(50 \%, \mathrm{RH}_{\max }\right] \\ \gamma_{\text {high }}, \mathrm{RH} \in\left(\mathrm{RH}_{\max }, 100 \%\right]\end{array}\right.$

where $i$ represents the reactant for heterogeneous reactions, $\mathrm{RH}_{\max }$ is the $\mathrm{RH}$ value at which the $\gamma$ reaches the upper limit, and $\gamma_{\text {low }}$ and $\gamma_{\text {high }}$ are the lower and upper limits of $\gamma$ values taken from Table 2 of Wang et al. (2012a) with one exception for R24.

In situ observations have found significant enhancement of $\mathrm{SO}_{2}$ oxidation rates under wet conditions, indicating possible missing heterogeneous reactions on deliquescent particles (Zheng et al., 2014b). However, the coefficients of $\mathrm{SO}_{2}$ uptake by aerosols (R24) are only established for ice surfaces and mineral dust particles (Kolb et al., 2010). As the parameterization of heterogeneous reaction of $\mathrm{SO}_{2}$ on soot, organics and SNA aerosols are not well established yet, we first arbitrarily selected the uptake coefficients from Wang et al. (2012a) and conducted four sensitivity runs (S1, S2, S3 and S4) by adjusting the uptake coefficients with a successive approximation approach. The parameters and evaluations of the four sensitivity runs are presented in the Supplement (Table S1 and Fig. S1). The $\gamma$ values of the lower and upper limits of $\mathrm{SO}_{2}$ recommended by Wang et al. (2012a) are $1.0 \times 10^{-4}$ and $2.6 \times 10^{-4}$, respectively, whereas other works recommended lower $\gamma$ values for $\mathrm{SO}_{2}$ - e.g., $4.0 \times 10^{-5}$ in Crowley et al. (2010), $1.35 \times 10^{-5}$ in Shang et al. (2010), and $0.6 \times 10^{-5}$ to $2.45 \times 10^{-4}$ in Wu et al. (2011). We found that using the $\gamma$ in Wang et al. (2012a) for R24 (sensitivity run S1) produced unreasonably high sulfate for this haze episode. We finally chose the value from S3 in our work, which can best match observations.

We assume the $\mathrm{RH}_{\max }$ of sulfate-related heterogeneous reaction (R24) to be $100 \%$, and that of nitrate-related heterogeneous reactions (R19-R21) to be $70 \%$. This assumption is made on the basis of the observational result that the SOR increases when the RH rises from 50 to $100 \%$ and the NOR increases when the RH rises from 50 to $70 \%$ and then stays stable when the RH continues to increase. The similar relationship between sulfur (nitrogen) conversion ratios and $\mathrm{RH}$ has also been reported in another pollution episode that occurred in the winter of 2011 in Beijing (Sun et al., 2013). For other heterogeneous reactions, we use the mean of lower and upper limit values in the model and assume that they remain constant under different RHs. 
Table 2. Domain, configurations and major physical options used in WRF v3.5.1.

\begin{tabular}{ll}
\hline Simulation period & Dec 2012 and Jan 2013 \\
\hline Domain & $\begin{array}{l}\text { East Asia (columns: 178, rows: 133) with three extra grids in } \\
\text { each boundary of Domain 1 (columns: 172, rows: 127) }\end{array}$ \\
\hline Horizontal resolution & $36 \mathrm{~km}$ \\
\hline Vertical resolution & 23 sigma levels from surface to tropopause (about 100 mb) \\
\hline Meteorological IC and BC & $\begin{array}{l}\text { Reanalysis data from the National Centers for Environmental } \\
\text { Prediction Final Analysis (NCEP-FNL) }\end{array}$ \\
\hline Shortwave radiation & New Goddard scheme (Chou et al., 1998) \\
\hline Longwave radiation & The rapid radiative transfer model (RRTM) (Mlawer et al., 1997) \\
\hline Land surface model & The USGS 24-category land use data \\
\hline Surface layer & Pleim-Xiu land surface scheme (Xiu and Pleim, 2001) \\
\hline Planetary boundary layer model & ACM2 PBL scheme (Pleim, 2007) \\
\hline Cumulus parameterization & Kain-Fritsch cumulus scheme (Kain, 2004) \\
\hline Cloud microphysics & WSM6 (Hong and Lim, 2006) \\
\hline Analysis nudging & $\begin{array}{l}\text { Temperature and water vapor mixing (above PBL); wind } \\
\text { (in and above PBL) }\end{array}$ \\
\hline Observational nudging & Temperature, water vapor mixing and wind (in and above PBL) \\
\hline Include soil moisture and temperature \\
\hline NCEP Automated Data Processing (ADP) surface (ds461.0) \\
and upper (ds351.0) air data
\end{tabular}

\section{Model configurations, simulation design and evaluation protocol}

\subsection{Model configurations and simulation design}

WRF/CMAQ simulations are performed over East Asia at a horizontal resolution of $36 \times 36 \mathrm{~km}$ (see Fig. 2). The simulation period is from 1 to 31 January 2013 with an additional 7 days used as a spin-up period to minimize the influence of initial conditions.

The physics options selected for the WRF simulation are summarized in Table 2. They are selected based on a number of initial simulations with different option combinations to ensure the best performance for meteorological predictions against observations during this episode. The meteorological initial and boundary conditions (ICs and BCs) are based on the National Centers for Environmental Prediction Final Analysis (NCEP-FNL) reanalysis data. The surface roughness is corrected by increasing the friction velocity by 1.5 times only in the boundary layer scheme to reduce the high biases in wind speed (Mass and Ovens, 2010).

The configurations and options used in the CMAQ model are summarized in Table 3. The gas-phase mechanism module is the CB05 gas-phase mechanism with active chlorine chemistry and updated toluene mechanism of Whitten et al. (2010). The aqueous-phase chemistry is based on the updated mechanism of the Regional Acid Deposition Model (RADM) model (Walcek and Taylor, 1986; Chang et al., 1987). The aerosol mechanism applied in this study is the AERO6 aerosol module. The photolytic rates are calculated in-line using simulated aerosols and ozone concentrations. The ICs and BCs are generated from the GEOS-Chem model (Bey et al., 2001).

Anthropogenic emissions for China in 2013 used in this work are derived from the MEIC model (Multi-resolution Emission Inventory of China, http://www.meicmodel.org). The MEIC model is a dynamic and technology-based emission model developed by Tsinghua University which estimates anthropogenic emissions for about 700 emitting sources over China with unified methodology (Zhang et al., 2007, 2009; Lei et al., 2011a). The MEIC model is an update of the bottom-up emission inventory developed by the same group (Zhang et al., 2007, 2009; Lei et al., 2011a) with several updates such as unit-based emission data for power plants (Wang et al., 2012b) and cement plants (Lei et al., 2011b), high-resolution vehicle emission inventory at county level (Zheng et al., 2014a), and new NMVOC mapping approach for different chemical mechanisms (Li et al., 2014). In the MEIC model, the latest available emission data with real 


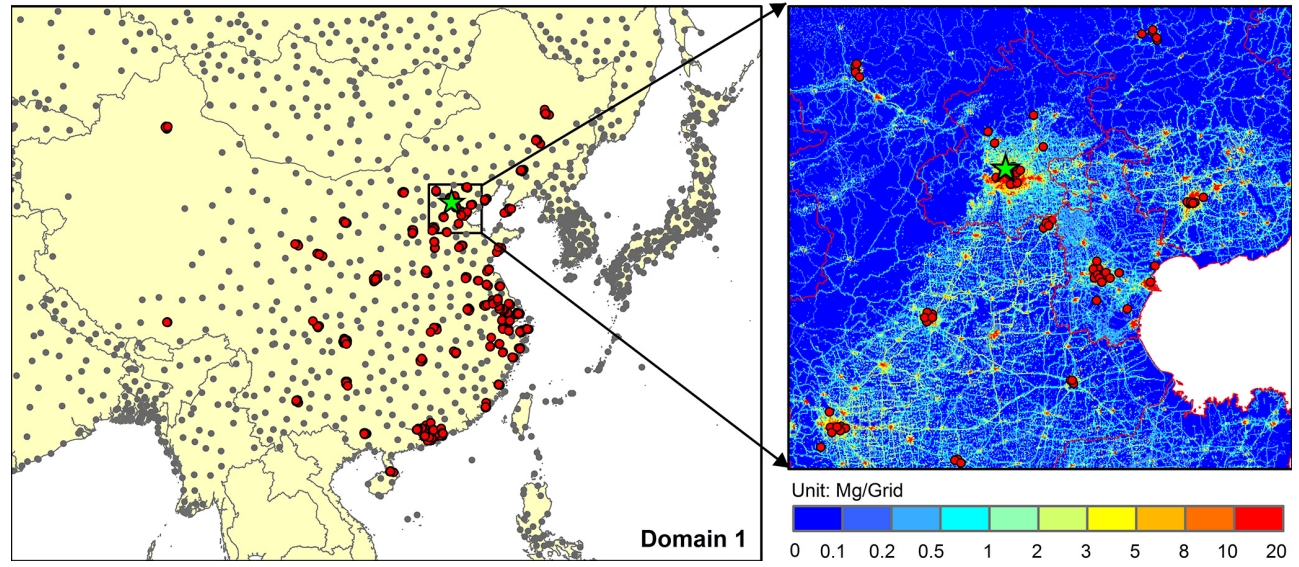

Figure 2. Simulation domain (Domain 1) and the monitoring stations. Gray circles are meteorological stations included in the NCDC data set and red circles are monitoring stations included in the CNEMC data set. Green star is the monitoring station at THU. Background in the enlarged map is $\mathrm{NO}_{\mathrm{x}}$ emission inventory of January 2013 at a horizontal resolution of $1 \mathrm{~km}$.

Table 3. Domain, configurations and options used in CMAQ v5.0.1.

\begin{tabular}{ll}
\hline Simulation period & 25 Dec 2012 to 31 Jan 2013 \\
\hline Domain & Domain 1 (columns: 172, rows: 127) \\
\hline Horizontal resolution & $36 \mathrm{~km}$ \\
\hline Vertical resolution & $\begin{array}{l}14 \text { sigma levels from surface to tropopause. The values of sigma levels are } 1.000,0.995,0.988, \\
0.980,0.970,0.956,0.938,0.893,0.839,0.777,0.702,0.582,0.400,0.200 \text { and } 0.000 .\end{array}$ \\
\hline IC and BC & GEOS-Chem $2^{\circ} \times 2.5^{\circ}$ global simulation \\
\hline Gas-phase mechanism & CB05 gas-phase mechanism with active chlorine chemistry and updated toluene mechanism of \\
\hline Aqueous-phase mechanism & The updated mechanism of the RADM model (Walcek and Taylor, 1986; Chang et al., 1987) \\
\hline Aerosol module & AERO6 \\
\hline Photolytic rate & Calculate photolytic rates in-line using simulated aerosols and ozone concentrations \\
\hline Cloud module & ACM cloud processor that uses the ACM methodology to compute convective mixing for AERO6 \\
\hline Windblown dust & $\begin{array}{l}\text { The physical-based dust emission algorithm FENGSHA } \\
\text { (http://www.airqualitymodeling.org/cmaqwiki/index.php?title=CMAQv5.0_Windblown_Dust) }\end{array}$ \\
\hline Lightning NO & $\begin{array}{l}\text { Not included, due to extremely low flash rates over the East Asia in winter } \\
\text { (Schumann and Huntrieser, 2007) }\end{array}$ \\
\hline
\end{tabular}

statistics at provincial level is for 2012. In this work, emissions for the year of 2013 are used from the extrapolation of the 2012 estimates and updated based on brief statistics at country level.

Anthropogenic emissions from the other Asian countries and biomass burning emissions are taken from the MIX emission inventory prepared for the Model Inter-comparison Study Asia Phase III (MICS-ASIA III). Biogenic emissions are calculated by the MEGAN v2.1 (Guenther et al., 2012). Sea salt emission and dust emission are calculated online on the basis of the algorithms developed by Gong (2003) and a physical-based dust emission algorithm FENGSHA (http://www.airqualitymodeling.org/cmaqwiki/index.php? title=CMAQv5.0_Windblown_Dust), respectively.

Using the WRF/CMAQ modeling system, the impacts of heterogeneous chemistry and the meteorological anomaly of 2013 on the significant production of sulfate and nitrate aerosols during the January 2013 haze episode are investigated with three simulations, as shown in Table 4. The simulation Original CMAQ uses the officially released version of CMAQ v5.0.1. In the simulation Revised CMAQ, nine important heterogeneous reactions are implemented in the model to explore the effects of heterogeneous chemistry. To further evaluate the impacts of the 2013 meteorological 

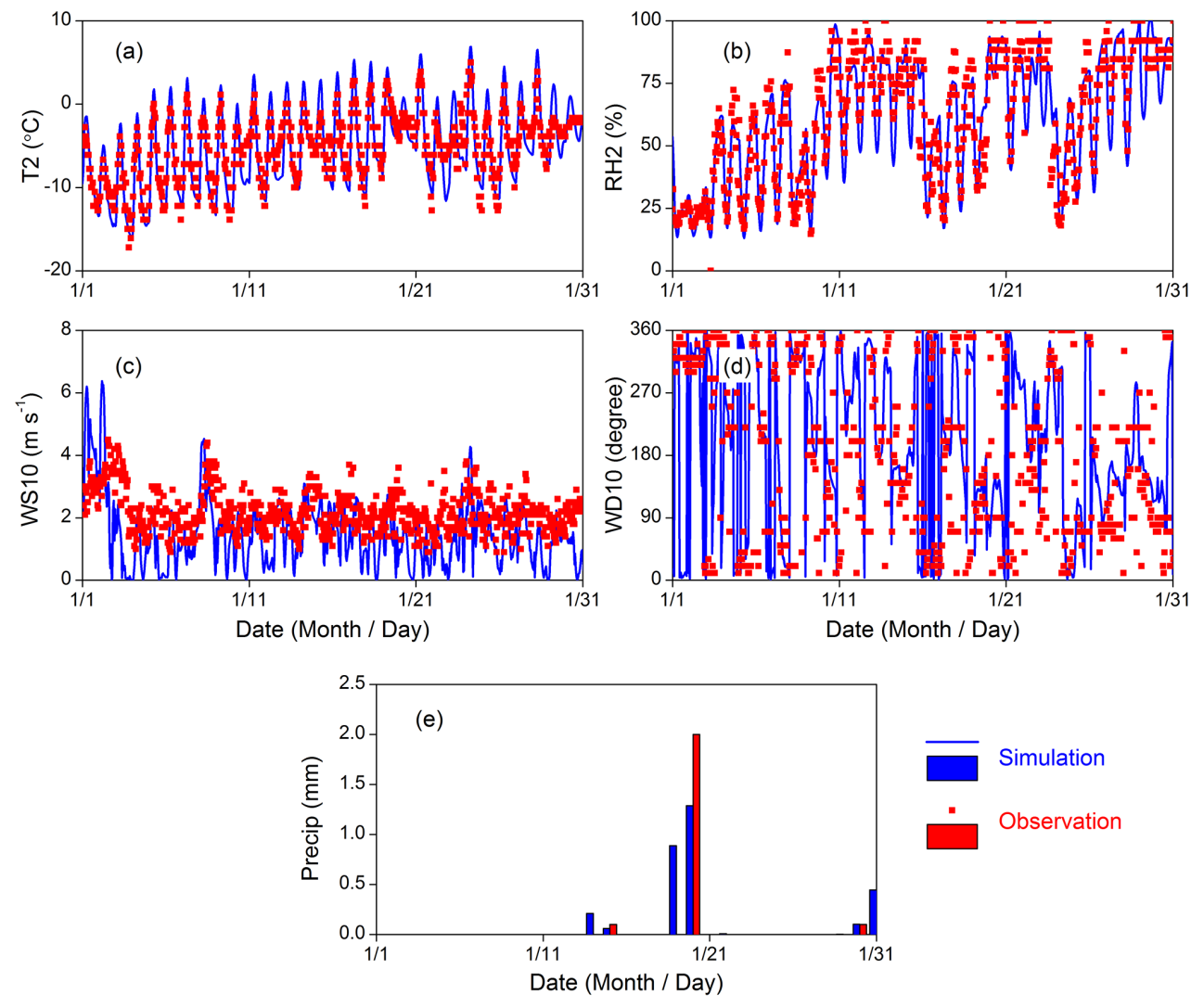

Figure 3. Observed and simulated meteorological variables at THU site: (a) hourly T2; (b) hourly RH2; (c) hourly WS10; (d) hourly WD10; (e) daily Precip.

anomaly on sulfate and nitrate production, another simulation with revised CMAQ is designed to use the same 2013 emissions but with the WRF meteorological predictions for 2012 (Revised CMAQ with 2013Emis\&2012Met). The uptake coefficients of heterogeneous chemistry used in the latter two simulations are presented in Table S2 of the Supplement.

\subsection{Evaluation protocol}

The model evaluation is performed in terms of domain-wide performance statistics and site-specific temporal variations. The performance statistics are conducted following the evaluation protocol of Zhang et al. (2006, 2011). The statistical parameters include correlation coefficient $(R)$, mean bias (MB), root mean square error (RMSE), NMB and normalized mean error (NME).

Table 5 summarizes the observational data sets used for model evaluation in this study. Three observational data sets are used including the meteorological data from the $\mathrm{Na}$ tional Climate Data Center (NCDC), the real-time gaseous and particulate concentrations in 74 cities from the China National Environmental Monitoring Center (CNEMC), and hourly concentrations of chemical species of $\mathrm{PM}_{2.5}$ from the ground-based measurement at the Tsinghua University site (THU) located in northwestern Beijing. A detailed description of these data sets can be found in the Supplement.

\section{Results and discussion}

\subsection{Evaluation of meteorological predictions}

Table 6 presents the statistical performances of the meteorological predictions, including temperature at $2 \mathrm{~m} \mathrm{(T2),} \mathrm{RH}$ at $2 \mathrm{~m}$ (RH2), wind speed at $10 \mathrm{~m}$ (WS10), wind direction at $10 \mathrm{~m}$ (WD10), and daily mean precipitation (Precip). The near-surface temperature agrees reasonably well with observations with $\mathrm{MBs}$ of $-0.8^{\circ} \mathrm{C}$. Simulated $\mathrm{RH} 2$ agrees well with observations across most of China with an NMB of $9.9 \%$ and an MB of $6.7 \%$. WS10 is overpredicted slightly with an NMB of $9.5 \%$ and an MB of $0.3 \mathrm{~m} \mathrm{~s}^{-1}$ for the $36 \mathrm{~km}$ domain. The MB of Precip is $1.1 \mathrm{~mm}$ and the NMB is $58.8 \%$ with a relatively poor performance compared with other meteorological variables. Precip is usually predicted with large biases by meteorological models (Zhang et al., 2011, 2012; Wang et al., 2014b), indicating the limited capability of a model to accurately reproduce the precipitating processes. The simulated meteorological variables show generally good 
Table 4. Simulation design.

\begin{tabular}{lllll}
\hline Run index & Emission & Meteorology & Model configuration & Purpose \\
\hline Original CMAQ & Jan 2013 & Jan 2013 & original CMAQ & $\begin{array}{l}\text { Examine the capability and } \\
\text { limitation of the original model } \\
\text { to study severe haze pollution }\end{array}$ \\
\hline Revised CMAQ & Jan 2013 & Jan 2013 & $\begin{array}{l}\text { revised CMAQ with } \\
\text { heterogeneous chemistry }\end{array}$ & $\begin{array}{l}\text { Evaluate the role of heterogeneous } \\
\text { chemistry in haze pollution }\end{array}$ \\
\hline $\begin{array}{l}\text { Revised CMAQ } \\
\text { with }\end{array}$ & Jan 2013 & Jan 2012 & $\begin{array}{l}\text { revised CMAQ with } \\
\text { heterogeneous chemistry }\end{array}$ & $\begin{array}{l}\text { Evaluate the impact of } \\
\text { meteorological anomaly of 2013 } \\
\text { on sulfate and nitrate production }\end{array}$ \\
\hline
\end{tabular}

agreement with observations, and the overall performances are consistent with similar work conducted for China using the Fifth-Generation Penn State/NCAR Mesoscale Model (MM5) or WRF models (Liu et al., 2010; Wang et al., 2010, 2014b; Zhang et al., 2011; Wang et al., 2012a; Fu et al., 2014). The simulated meteorological variables agree well with observations in terms of temporal variations and magnitudes at the THU site (as shown in Fig. 3), confirming the reliability of meteorological prediction at location with SNA observation data.

\subsection{Chemical predictions of the original CMAQ at THU site}

\subsubsection{Sulfate, nitrate and ammonium}

Figure 4 compares the temporal variations of aerosol compositions in January 2013 simulated by the original CMAQ with observation at the THU site, and the statistical performance of the model is summarized in Table 7. Although the original CMAQ model only underpredicts $\mathrm{PM}_{2.5}$ mass concentration by $21.9 \%$, it significantly underpredicts $\mathrm{SO}_{4}^{2-}, \mathrm{NO}_{3}^{-}$ and $\mathrm{NH}_{4}^{+}$concentration with NMBs of $-54.2 \%,-40.0 \%$ and $-58.1 \%$, respectively. The modeled hourly $\mathrm{PM}_{2.5}$ concentration shows good agreement with the observations when the $\mathrm{PM}_{2.5}$ concentration is below $450 \mu \mathrm{g} \mathrm{m}^{-3}$. However, the model failed to predict SNA variations during the polluted days, leading to a large underprediction of total $\mathrm{PM}_{2.5}$ mass concentration during the heavy haze episodes when SNA are dominant compositions in total $\mathrm{PM}_{2.5}$ mass. Figure 5a illustrates the enhancement of SNA in $\mathrm{PM}_{2.5}$ in haze days in January 2013 at the THU site. The contribution of SNA to total $\mathrm{PM}_{2.5}$ mass increased from 29.3 to $50.3 \%$ from clean days to heavily polluted days due to the increased conversion rates of $\mathrm{SO}_{2}$ and $\mathrm{NO}_{2}$ under the haze condition (Sun et al., 2013, 2014), while the original CMAQ model could not reproduce the dominant contribution of SNA to $\mathrm{PM}_{2.5}$ for those episodes, indicating that some mechanisms that might have significant impacts on $\mathrm{SO}_{4}^{2-}$ and $\mathrm{NO}_{3}^{-}$formation during haze episodes are absent in the original CMAQ model.
As discussed in Sect. 2.2, we believe that heterogeneous chemistry played a key role in sulfate and nitrate production under the haze condition. Nine heterogeneous reactions have been incorporated into the original CMAQ model to improve the model capability in reproducing the observed high concentrations of sulfate and nitrate and study the role of these reactions in the haze pollution. The simulation results from the revised CMAQ with these heterogeneous reactions are described in Sect. 4.3.

\subsubsection{Carbonaceous aerosols}

As shown in Fig. 4, the original CMAQ model can generally capture the temporal variation of element carbon at the THU site but has a positive bias of $196.2 \%$ in monthly mean concentration, implying large overestimation of element carbon emissions in the MEIC inventory for the urban Beijing area. The MEIC inventory used in this work is first calculated by province and then allocated to grids by uniformed spatial proxies across provinces, which may induce significant bias for specific locations. Coal boilers and stoves have been phased out from Beijing urban areas and diesel trucks are also prohibited from entering the urban center of Beijing during daytime. These local policies are not considered in MEIC emission inventory, which may lead to the overestimation of element carbon emissions in Beijing urban areas. For organic carbon, the large bias only exists during haze days with mass concentrations larger than $60 \mu \mathrm{g} \mathrm{m}^{-3}$. As the secondary organic aerosol (SOA) module used in CMAQ does not include the formation pathways of heterogeneous reactions involving VOCs and SVOCs, and oligomerization during the haze events and multi-generations of gas-phase oxidations of semi-VOCs (SVOCs), the underestimation is probably caused by the underpredictions in SOA.

\subsection{Improvements of SNA predictions by the revised CMAQ with heterogeneous chemistry}

Figure 4 compares the temporal variations of $\mathrm{PM}_{2.5}, \mathrm{SO}_{4}^{2-}$, $\mathrm{NO}_{3}^{-}, \mathrm{NH}_{4}^{+}, \mathrm{OC}$ and EC at the THU site simulated by the original and revised $\mathrm{CMAQ}$ with observations. The sulfate 
Table 5. Observational data for model evaluation.

\begin{tabular}{|c|c|c|c|c|c|c|}
\hline Data set & Data & Variable $^{\mathrm{d}}$ & Frequency & $\begin{array}{c}\text { Site } \\
\text { number }\end{array}$ & Time period & Sources \\
\hline $\mathrm{NCDC}^{\mathrm{a}}$ & Meteorology & $\begin{array}{l}\text { T2, RH2, } \\
\text { WS10, } \\
\text { WD10 and } \\
\text { Precip }\end{array}$ & $\begin{array}{c}\text { Every } 1 \\
\text { or } 3 \mathrm{~h}\end{array}$ & $\sim 1000$ & $\begin{array}{c}1-31 \text { Jan } \\
2013\end{array}$ & ftp://ftp.ncdc.noaa.gov/pub/data/noaa/ \\
\hline $\mathrm{CNEMC}^{\mathrm{b}}$ & $\begin{array}{l}\text { Gaseous and } \\
\text { particulate } \\
\text { species }\end{array}$ & $\begin{array}{l}\mathrm{SO}_{2}, \mathrm{NO}_{2}, \\
\mathrm{CO}, \mathrm{PM}_{2.5} \\
\text { and } \mathrm{PM}_{10}\end{array}$ & Hourly & 496 & $\begin{array}{c}1-31 \text { Jan } \\
2013\end{array}$ & http://113.108.142.147:20035/emcpublish/ \\
\hline $\mathrm{THU}^{\mathrm{c}}$ & $\begin{array}{c}\text { Particulate } \\
\text { species }\end{array}$ & $\begin{array}{c}\mathrm{PM}_{2.5}, \\
\mathrm{SO}_{4}^{2-}, \mathrm{NO}_{3}^{-}, \\
\mathrm{NH}_{4}^{+}, \mathrm{EC} \text { and } \mathrm{OC}\end{array}$ & Hourly & 1 & $\begin{array}{c}\text { 1-31 Jan } \\
2013\end{array}$ & Zheng et al. (2014b) \\
\hline
\end{tabular}

a NCDC: meteorological data obtained from the National Climate Data Center.

b CNEMC: gaseous and particulate concentrations obtained from the China National Environmental Monitoring Center.

${ }^{c}$ THU: particulate species concentration measured at Tsinghua University.

$\mathrm{d}$ T2: temperature at $2 \mathrm{~m}$; RH2: relative humidity at $2 \mathrm{~m}$; WS10: wind speed at $10 \mathrm{~m}$; WD10: wind direction at $10 \mathrm{~m}$; Precip: daily precipitation.

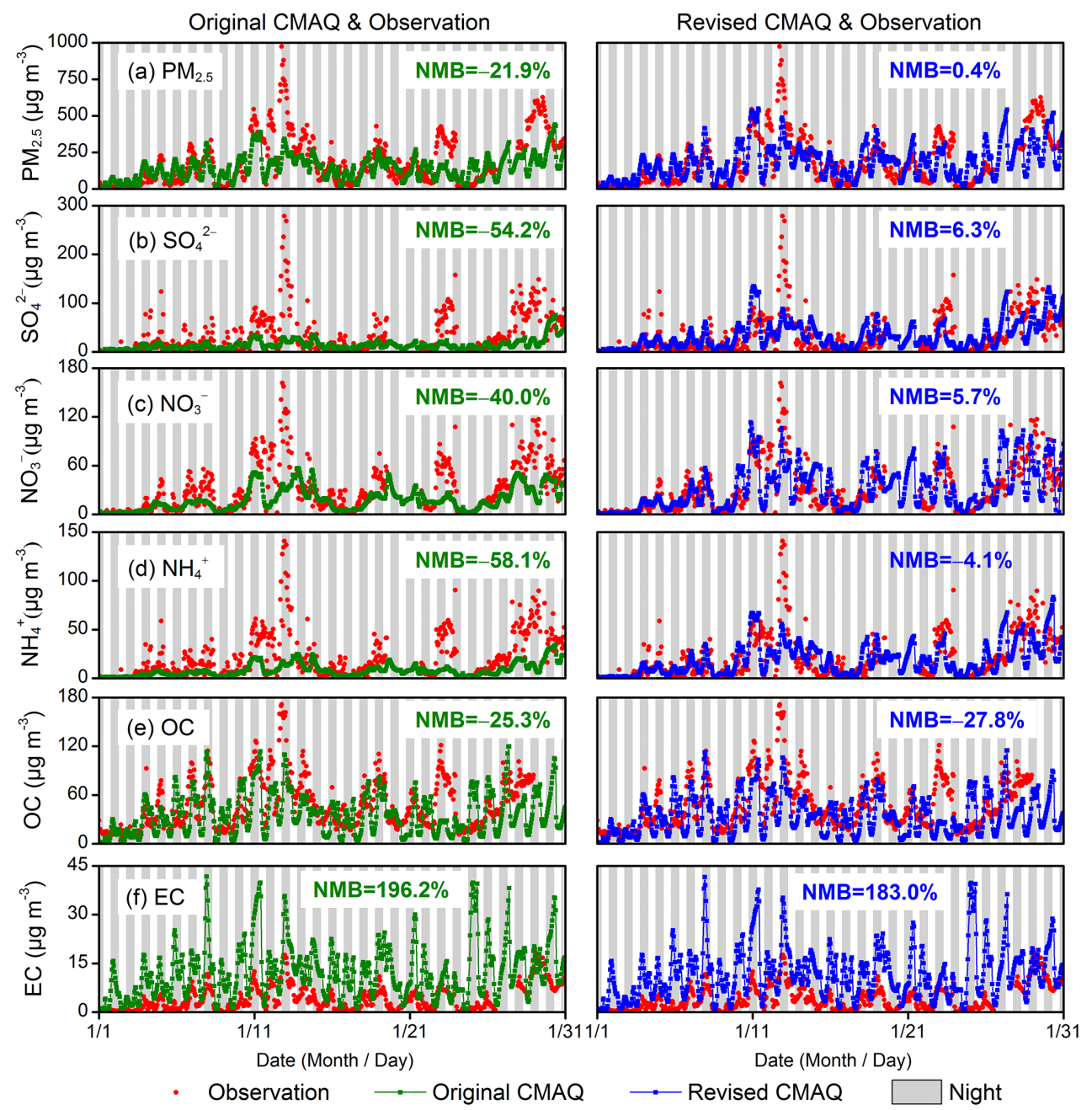

Figure 4. Observed and simulated hourly aerosol compositions from the original and revised CMAQ at the $\mathrm{THU}$ site: (a) $\mathrm{PM}_{2.5}$; (b) $\mathrm{SO}_{4}^{2-}$; (c) $\mathrm{NO}_{3}^{-} ;$(d) $\mathrm{NH}_{4}^{+} ;$(e) $\mathrm{OC}$; (f) $\mathrm{EC}$. 
Table 6. Performance statistics of WRF simulation.

\begin{tabular}{lrrrrr}
\hline & $\mathrm{T}^{\mathrm{a}}$ & $\mathrm{RH}^{\mathrm{a}}$ & $\mathrm{WS}^{\mathrm{a}} 0^{\mathrm{a}}$ & $\mathrm{WD}^{\mathrm{a}}$ & Precip $^{\mathrm{a}}$ \\
\hline Data pairs $^{\mathrm{b}}$ & 385753 & 385103 & 385165 & 336507 & 488 \\
MeanObs $^{\mathrm{b}}$ & -0.2 & 67.5 & 2.7 & 227.1 & 1.8 \\
MeanSim $^{\mathrm{b}}$ & -1.1 & 74.1 & 3.0 & 205.6 & 2.9 \\
$R^{\mathrm{b}}$ & 1.0 & 0.7 & 0.6 & 0.3 & 0.4 \\
MB $^{\mathrm{b}}$ & -0.8 & 6.7 & 0.3 & -21.6 & 1.1 \\
RMSE $^{\mathrm{b}}$ & 3.5 & 14.9 & 2.1 & 177.2 & 7.9 \\
${\text { NMB }(\%)^{\mathrm{b}}}^{\mathrm{b}}$ & -389.5 & 9.9 & 9.5 & -9.5 & 58.8 \\
NME $(\%)^{\mathrm{b}}$ & 1211.3 & 17 & 57.9 & 41.9 & 145 \\
\hline
\end{tabular}

a Definitions of these variables can be found in the footnotes of Table 5. The units of T2, RH2, WS10, WD10 and Precip are ${ }^{\circ} \mathrm{C}, \%, \mathrm{~m} \mathrm{~s}^{-1}$, degree and $\mathrm{mm} \mathrm{day}^{-1}$, respectively. The T2, RH2, WS10 and WD10 are evaluated using hourly data and the Precip is evaluated using daily data

b Data pairs: the number of observed and simulated data pairs; MeanObs: mean observational data; MeanSim: mean simulation results; $R$ : correlation coefficient; MB: mean bias; RMSE: root mean square error; NMB: normalized mean bias; NME: normalized mean error.

and nitrate simulations with heterogeneous chemistry are improved significantly in terms of both magnitude and temporal variation. In particular, the significant discrepancies in $\mathrm{PM}_{2.5}, \mathrm{SO}_{4}^{2-}, \mathrm{NO}_{3}^{-}$and $\mathrm{NH}_{4}^{+}$between the observed and simulated concentrations during severely polluted days are improved, although a couple of observed peak values are still not captured well. The synergic improvement of SNA predictions illustrates the significant role heterogeneous chemistry plays in the haze pollution events. The revised CMAQ shows better performance with NMBs of 0.4, 6.3, 5.7 and $-4.1 \%$, for $\mathrm{PM}_{2.5}, \mathrm{SO}_{4}^{2-}, \mathrm{NO}_{3}^{-}$and $\mathrm{NH}_{4}^{+}$, respectively. The $\mathrm{MBs}$ of sulfate and nitrate are reduced, changing from -17.8 to $2.1 \mu \mathrm{g} \mathrm{m}^{-3}$ and from -12.3 to $1.8 \mu \mathrm{g} \mathrm{m}^{-3}$, respectively. As expected, the simulated level of $\mathrm{PM}_{2.5}$ is also improved with MBs changing from -40.8 to $0.8 \mu \mathrm{g} \mathrm{m}^{-3}$.

It should be noted that the revised CMAQ model still significantly underestimated the peak $\mathrm{PM}_{2.5}$ concentration on 13 January 2013. Zheng et al. (2014b) argued that the abrupt increase of $\mathrm{PM}_{2.5}$ concentration on 13 January represented rapid recovery from an interruption to the continuous pollution accumulation over the region rather than local chemical production. Our model also failed to predict the high $\mathrm{PM}_{2.5}$ concentration on 13 January over the polluted region (e.g., Langfang and Shijiazhuang, see Supplement), but agreed well with observation in upwind cities (e.g., Chengde). In this case, the model may have underestimated the regional transport in polluted areas given the fact that the wind speed was underestimated at the THU site.

The revised CMAQ can capture the enhancement of relative contribution of SNA from clean days to polluted days, as shown in Fig. 5. Observations show that the fractions of SNA increase rapidly to $42.2 \%$ and $50.3 \%$ on polluted and heavily polluted days, which are well reproduced by the revised CMAQ with fractions of $49.0 \%$ and $52.6 \%$. For comparison, the original CMAQ gives SNA fractions of $32.1 \%$ and $30.8 \%$, which are considerably lower. During polluted and heavily polluted days, there exist significant discrepancies in

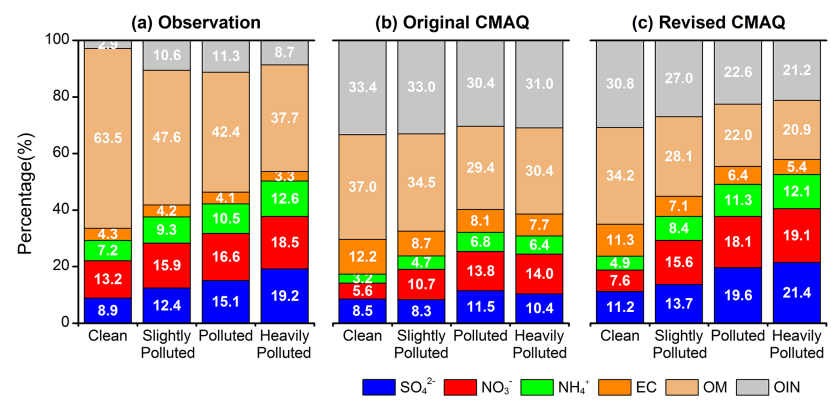

Figure 5. Percentile compositions of major components in $\mathrm{PM}_{2.5}$ derived from (a) Observation; (b) Original CMAQ; (c) Revised CMAQ with enhanced heterogeneous chemistry. The pollution is classified into four types: clean $\left(\mathrm{PM}_{2.5} \leq 35 \mu \mathrm{g} \mathrm{m}^{-3}\right)$, slightly polluted $\left(35<\mathrm{PM}_{2.5} \leq 115 \mu \mathrm{g} \mathrm{m}^{-3}\right)$, polluted $\left(115<\mathrm{PM}_{2.5}\right.$ $\left.\leq 350 \mu \mathrm{g} \mathrm{m}^{-3}\right)$ and heavily polluted $\left(\mathrm{PM}_{2.5}>350 \mu \mathrm{g} \mathrm{m}^{-3}\right)$, based on the China's Air Quality Index (AQI) level definition (http://kjs.mep.gov.cn/hjbhbz/bzwb/dqhjbh/jcgfffbz/201203/ W020120410332725219541.pdf).

SNA percentage contributions between the original and revised CMAQ, indicating the important role of heterogeneous chemistry in haze pollution. It should be noted that the good agreement between the revised CMAQ and observations is highly dependent on the selections of uptake coefficients, as discussed in Sect. 2.2. However, all sensitivity runs can reproduce the enhancement of relative contribution of sulfate in haze days (Fig. S1), implying the importance of heterogeneous chemistry. Laboratory measurements of uptake coefficients on the surfaces of mixed and deliquescent aerosols will help to confirm our findings in the future.

The evolution patterns of SNA simulated by the revised CMAQ are also generally consistent with other field observations on haze episodes in China, which confirmed the significance of heterogeneous chemistry in the haze formation process over China. The enhanced SNA contribution in haze 
Table 7. Performance statistics of the original and revised CMAQ model at the THU site.

\begin{tabular}{llrrrrrr}
\hline & & $\mathrm{PM}_{2.5}^{\mathrm{a}}$ & $\mathrm{SO}_{4}^{2-}$ & $\mathrm{NO}_{3}^{-}$ & $\mathrm{NH}_{4}^{+}$ & $\mathrm{EC}$ & $\mathrm{OC}$ \\
\hline Obs & & 186.0 & 32.8 & 30.7 & 20.8 & 4.2 & 47.3 \\
Original CMAQ & MeanSim & 145.2 & 15.0 & 18.4 & 8.7 & 12.3 & 35.3 \\
& $R$ & 0.8 & 0.6 & 0.8 & 0.7 & 0.6 & 0.8 \\
& $\mathrm{MB}$ & -40.8 & -17.8 & -12.3 & -12.1 & 8.2 & -12.0 \\
& $\mathrm{RMSE}$ & 102.3 & 30.5 & 19.6 & 18.5 & 9.0 & 19.9 \\
& NMB (\%) & -21.9 & -54.2 & -40.0 & -58.1 & 196.2 & -25.3 \\
& NME (\%) & 33.8 & 57.4 & 42.0 & 59.0 & 196.2 & 29.2 \\
Revised CMAQ & MeanSim & 186.8 & 34.8 & 32.4 & 19.9 & 11.8 & 34.2 \\
& $\mathrm{R}$ & 0.8 & 0.7 & 0.8 & 0.8 & 0.6 & 0.7 \\
& MB & 0.8 & 2.1 & 1.8 & -0.8 & 7.6 & -13.1 \\
& $\mathrm{RMSE}$ & 83.3 & 21.2 & 14.6 & 11.6 & 8.4 & 21.2 \\
& $\mathrm{NMB}(\%)$ & 0.4 & 6.3 & 5.7 & -4.1 & 183.0 & -27.8 \\
& NME $(\%)$ & 33.1 & 46.8 & 35.3 & 39.4 & 183.8 & 31.7 \\
\hline
\end{tabular}

a The units of $\mathrm{PM}_{2.5}, \mathrm{SO}_{4}^{2-}, \mathrm{NO}_{3}^{-}, \mathrm{NH}_{4}^{+}, \mathrm{OC}$ and $\mathrm{EC}$ are all $\mu \mathrm{g} \mathrm{m}{ }^{-3}$.

days compared to clean days were also observed in other field campaigns, where the heterogeneous chemistry was attributed as the most probable pathway of observed abrupt increases in SNA aerosols as the oxidation rates of gasphase and aqueous-phase chemistry were too slow (Zhao et al., 2013b; Ji et al., 2014; Quan et al., 2014; Wang et al., 2014c). Strong correlations between RH and sulfur and nitrogen oxidation ratios (SOR and NOR) were found during haze episodes (Wang et al., 2012c, 2014c; Sun et al., 2014; Zheng et al., 2014b) with sharp increase of SOR and NOR when RH exceeds $50 \%$, lending support to our assumptions in the revised CMAQ.

The revised CMAQ gives very similar OC and EC predictions as original CMAQ, with large underpredictions in OC during the haze episodes but overpredictions in EC throughout the simulation period for the reasons discussed previously in Sect. 4.2.2. The percentage contributions for EC and OIN are also slightly decreased especially in the polluted and heavily polluted days. This is because the mode-averaging particle diameter is larger due to the enhanced formation of SNA when the heterogeneous reactions are included. The particle settling velocity is increased and thus dry deposition rates are larger, which helps reduce the overpredictions of these species.

\subsection{Domain-wide impact from the implementation of heterogeneous chemistry}

The simulation results with and without heterogeneous chemistry are compared over the whole domain to evaluate the impact of heterogeneous reactions during the January 2013 haze episode. Table 8 summarizes the statistical performance for surface concentrations of $\mathrm{CO}, \mathrm{NO}_{2}, \mathrm{SO}_{2}$, $\mathrm{PM}_{2.5}$ and $\mathrm{PM}_{10}$ from the simulation with original CMAQ and revised CMAQ for 74 cities in China. The original CMAQ model can generally reproduce the concentrations of aerosol and gaseous pollutants over the whole domain. The model underpredicts the concentrations of $\mathrm{CO}$ and $\mathrm{PM}_{10}$ with NMBs of -20.6 and $-11.2 \%$, respectively, and overpredicts those of $\mathrm{SO}_{2}, \mathrm{NO}_{2}$ and $\mathrm{PM}_{2.5}$ with NMBs of 51.2, 13.4 and $8.1 \%$, respectively. As expected, the overpredictions in $\mathrm{SO}_{2}$ and $\mathrm{NO}_{2}$ are improved in the revised CMAQ model because the added heterogeneous reactions enhance their conversions to sulfate and nitrate. The positive biases of $\mathrm{SO}_{2}$ and $\mathrm{NO}_{2}$ are reduced from 51.2 to $38.5 \%$ and 13.4 to $11.2 \%$. We further found that high $\mathrm{NMB}$ in $\mathrm{SO}_{2}$ prediction is mainly contributed by provincial capital cities. As the most developed cities within China, the provincial capital cities tend to prohibit coal use in urban areas or use high-quality coal with low sulfur content, which has not been accurately represented in regional emission inventories which are compiled at the provincial level. As a result, $\mathrm{SO}_{2}$ emissions from those capital cities may have been overestimated.

Figure 6 illustrates the concentration of SNA and $\mathrm{PM}_{2.5}$ simulated by the original and revised CMAQ and Fig. 7 further explores the difference in heavily polluted regions. Heterogeneous chemistry enhances SNA concentrations significantly in the most polluted regions in China (the Northeast Plain (NP), NCP, Middle-Lower Yangtze Plain (MLYP), and Sichuan Basin (SB)), leading to the increased $\mathrm{PM}_{2.5}$ concentration over those regions. In southern China (e.g., the Pearl River Delta (PRD)), sulfate concentration is still increased but nitrate concentration is decreased by $5-20 \mu \mathrm{g} \mathrm{m}^{-3}$, resulting in a reduction of $\mathrm{PM}_{2.5}$ concentration by $10-20 \mu \mathrm{g} \mathrm{m}^{-3}$. The contrasting responses to heterogeneous chemistry in different regions are because of the complex thermodynamic processes of SNA formation, which differ greatly under $\mathrm{NH}_{3}$-rich and $\mathrm{NH}_{3}$-poor conditions. The polluted regions listed above (NP, NCP, MLYP, and SB) are all $\mathrm{NH}_{3}$-rich regions (Wang et al., 2011; Zhao et al., 2013a), as shown in Fig. 7a, which comprise $24.5 \%$ land areas in China but 

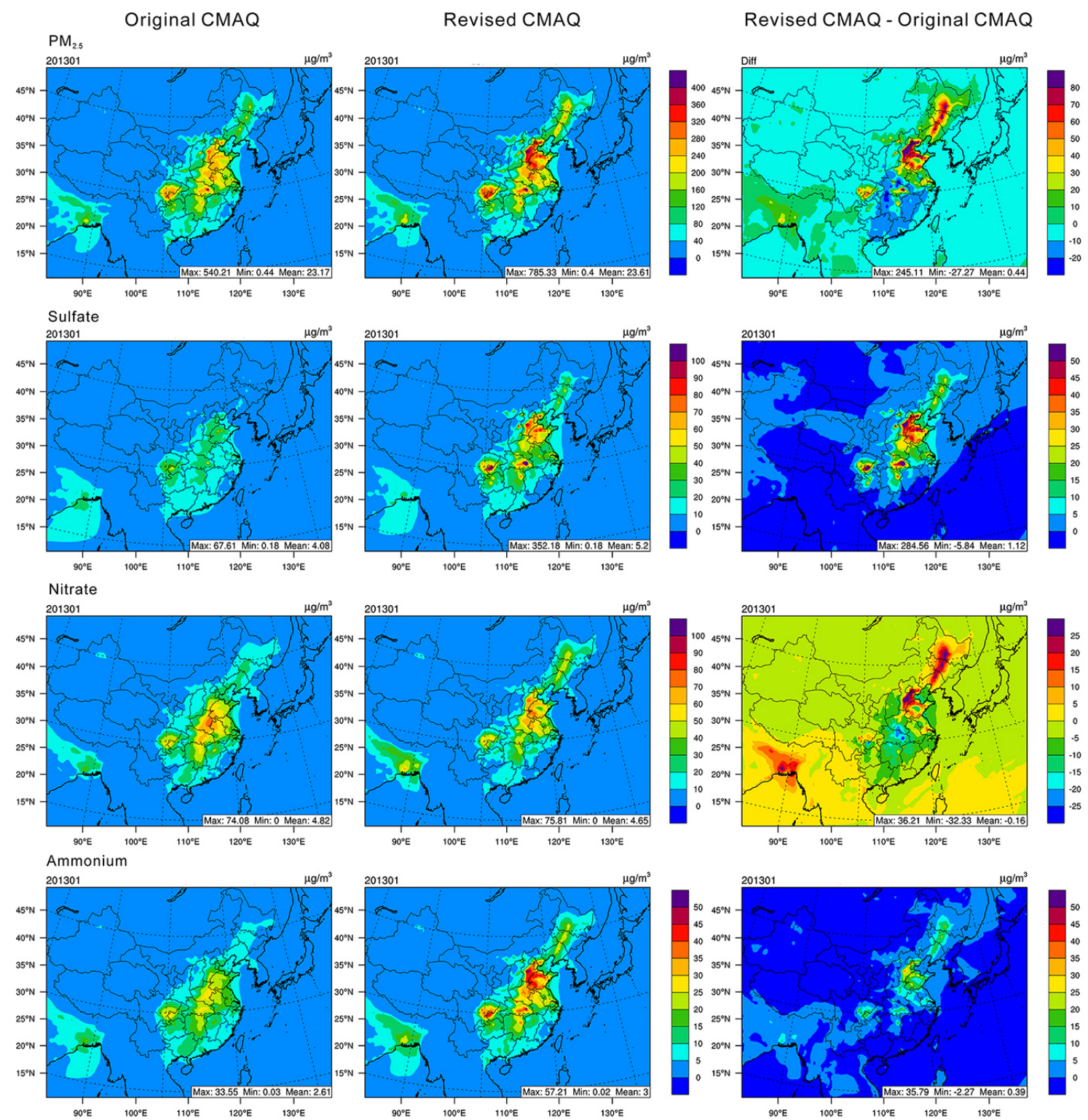

Figure 6. Spatial distributions of monthly (January 2013) mean concentrations of $\mathrm{PM}_{2.5}$, sulfate, nitrate and ammonium simulated by the Original CMAQ (left), Revised CMAQ (middle) and the differences between the Revised and Original CMAQ (right).

contribute to $47.4 \%$ cultivated lands (National Bureau of Statistics, 2013) and $48.3 \% \mathrm{NH}_{3}$ emissions (derived from the MEIC model). The abundant $\mathrm{NH}_{3}$ emissions provide sufficient amounts of ammonium to neutralize the increased amounts of sulfate and nitrate formed through heterogeneous chemistry; therefore, the total amount of $\mathrm{PM}_{2.5}$ in these regions increases with enhancement of both sulfate and nitrate. This causes the positive bias of simulated $\mathrm{PM}_{2.5}$ to be larger in the $\mathrm{NH}_{3}$-rich regions, mainly contributed by the overpredictions of EC and OIN. In southern China, which is an $\mathrm{NH}_{3}-$ poor region in January (Wang et al., 2011), sulfate and nitrate compete for ammonium and the formation of ammonium sulfate occurs first owing to its more thermodynamically stable characteristics - increased levels of sulfate would thus lead to a decrease of nitrate. This phenomenon could even lead to a decrease in the total concentration of $\mathrm{PM}_{2.5}$, because to neutralize with the same amount of ammonium, the mass of sulfate required is smaller than that of nitrate.

\subsection{Impact of meteorology in 2013 on SNA production}

The haze episode in January 2013 was the most serious pollution event in recent years. Why it should happen in 2013 but not in other years is an intriguing question. Emissions of $\mathrm{SO}_{2}, \mathrm{NO}_{\mathrm{x}}$, and $\mathrm{PM}_{2.5}$ were stable during 2011-2013 (derived from the MEIC model), indicating that emissions are not the critical driving force. The anomalous meteorological 


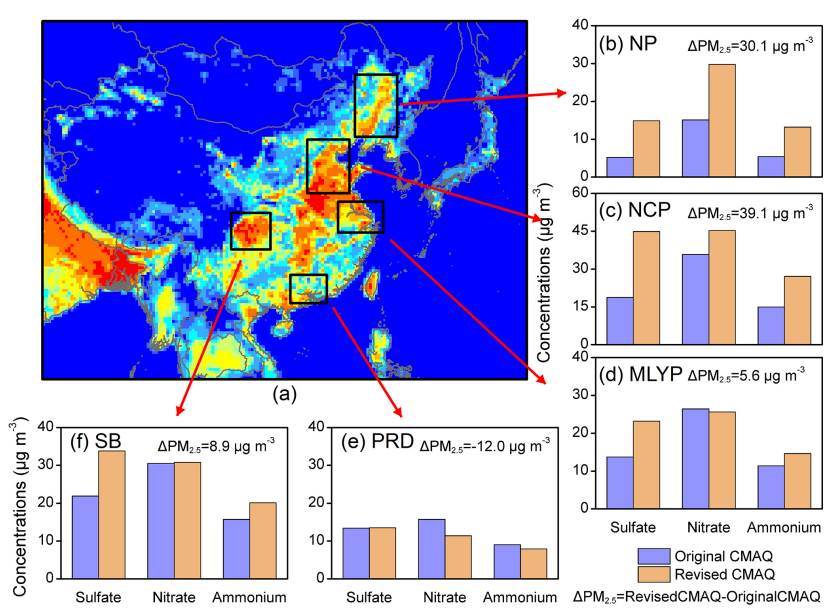

Figure 7. Comparison of predicted SNA from Original and Revised CMAQ for (b) NP, (c) NCP, (d) MLYP, (e) PRD and (f) SB. (a) Emission map of $\mathrm{NH}_{3}$ in January 2013 at a horizontal resolution of $36 \mathrm{~km}$ (source: MEIC model).

conditions (low temperature, high RH, and low wind speed) in January 2013 are identified as the key influence factor of haze formation by affecting radiation, horizontal transport, vertical mixing, and the atmospheric reaction rates of air pollutants (Ding and Liu, 2014; Wang et al., 2014d). As described in Sect. 2.2, meteorological conditions (specifically $\mathrm{RH})$ can affect heterogeneous chemistry by increasing the uptake coefficients of gases. In this section, the impact of the 2013 meteorological conditions on the production of sulfate and nitrate is evaluated using the revised CMAQ with heterogeneous chemistry.

The meteorological conditions of 2012 are selected to represent typical weather conditions because they were very close to the 10-year average climatology conditions with regard to temperature, RH, wind speed, and sea level pressure (data derived from http://cdc.cma.gov.cn) in the region of the NCP. Figure 8 illustrates the spatial distributions of the monthly mean temperature, $\mathrm{RH}, \mathrm{PM}_{2.5}$, sulfate, and nitrate simulated by the revised CMAQ with the meteorological fields of 2012 and 2013. The simulated temperature of 2013 in North and East China is $2-3{ }^{\circ} \mathrm{C}$ lower than that in 2012 and the simulated RH is $5-25 \%$ higher. High RH promotes heterogeneous conversions to generate more sulfate and nitrate and therefore, to increase the total concentration of $\mathrm{PM}_{2.5}$. Significant differences in RH occur in the NCP region, where increases by 15-30\% in RH correspond to increases of $\mathrm{PM}_{2.5}$ concentration by $70-150 \mu \mathrm{g} \mathrm{m}^{-3}$.

Traditional chemistry mechanisms play a relatively small role during haze formation because of the low solar radiation and low-temperature conditions, and few precipitating clouds, whereas heterogeneous chemistry mechanisms are enhanced by the extremely high $\mathrm{RH}$, which leads to the significant production of sulfate and nitrate aerosols. This provides a perspective to understand how adverse meteorolog- ical conditions can affect air quality through reaction pathways that are sensitive to specific meteorological variables. The meteorological anomaly of 2013 occurred not only for temperature and $\mathrm{RH}$, but also for other variables - for example, the shallower PBL and lower wind speed than a typical year. The abnormal changes in these variables also have adverse effects on haze pollution. For example, the height of the PBL across China in 2013 was about $200 \mathrm{~m}$ lower than in 2012, which could weaken and confine the vertical mixing of pollutants and thus aggravate surface pollution. Researches on the impact of these factors have been reported in other studies (e.g., Wang et al., 2014d; Zhang et al., 2014b).

\section{Summary and conclusions}

In this work, the WRF/CMAQ has been applied to simulate the January 2013 haze episode in China and evaluate the role heterogeneous chemistry played in the formation of sulfate and nitrate during this episode. The simulations with the original and the revised CMAQ are performed and evaluated. In the simulation by original CMAQ, $\mathrm{PM}_{2.5}, \mathrm{SO}_{4}^{2-}, \mathrm{NO}_{3}^{-}$ and $\mathrm{NH}_{4}^{+}$are underpredicted with $\mathrm{NMBs}$ of $-21.9,-54.2$, -40.0 and $-58.1 \%$, respectively, at the THU site. The incorporation of additional heterogeneous chemistry into CMAQ v5.0.1 significantly improves the model's capability in reproducing sulfate and nitrate concentrations, which are the most important $\mathrm{PM}_{2.5}$ compositions on polluted haze days. The revised CMAQ shows better performances with NMBs of $0.4,6.3,5.7$ and $-4.1 \%$, for $\mathrm{PM}_{2.5}, \mathrm{SO}_{4}^{2-}, \mathrm{NO}_{3}^{-}$and $\mathrm{NH}_{4}^{+}$, respectively, at the THU site. The MBs of sulfate and nitrate are reduced, changing from -17.8 to $2.1 \mu \mathrm{g} \mathrm{m}^{-3}$ and from -12.3 to $1.8 \mu \mathrm{g} \mathrm{m}^{-3}$, respectively. The revised CMAQ with enhanced heterogeneous chemistry not only captures the magnitude and temporal variation of SNA concentrations, but also reproduces the enhancement of SNA compositions from clean air to polluted haze days, both of which indicate the significantly improved capability of the revised model for haze studies. The revised CMAQ model is then used to evaluate the impact of both heterogeneous chemistry on haze formation during January 2013 and of the meteorological anomaly in 2013 on heterogeneous generation of sulfate and nitrate.

Compared with previous studies focusing on the haze episode of January 2013, this work provides a unique method to explore the formation mechanisms of severe haze by evaluating initial application of the original CMAQ, identifying missing heterogeneous chemistry based on model performance, and then incorporating those missing reactions into CMAQ. It thus provides a mechanistic level of understanding of the formation mechanism of the severe regional haze pollution episode.

This study has several limitations. First, heterogeneous chemistry is implemented into CMAQ with several assumptions. For example, a pseudo-first-order rate constant is as- 


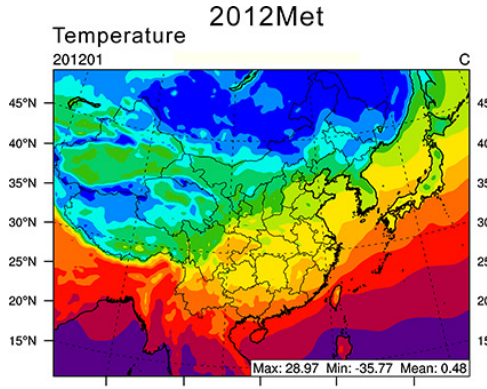

$90^{\circ} \mathrm{E} \quad 100^{\circ} \mathrm{E} \quad{ }_{110^{\circ} \mathrm{E}} \quad 120^{\circ} \mathrm{E} \quad 130^{\circ} \mathrm{E}$

Relative humidity

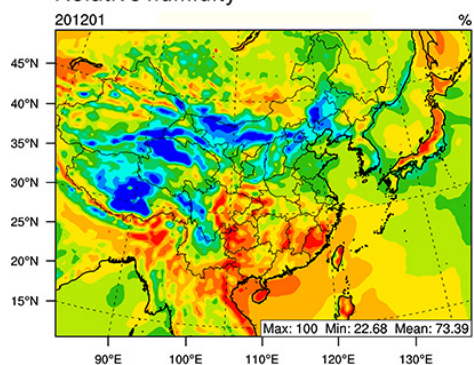

90

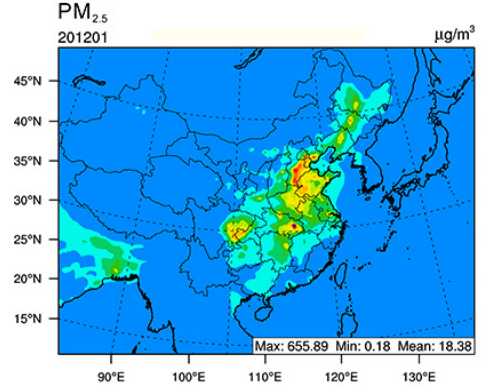

${ }^{90^{\circ} \mathrm{E}}$

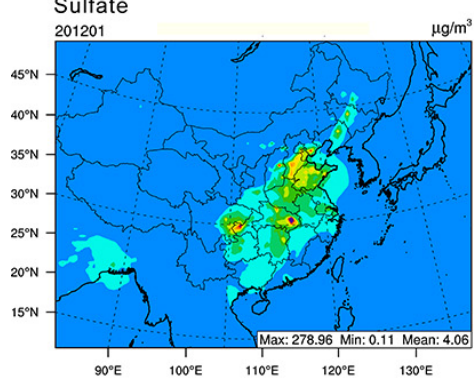

itrate

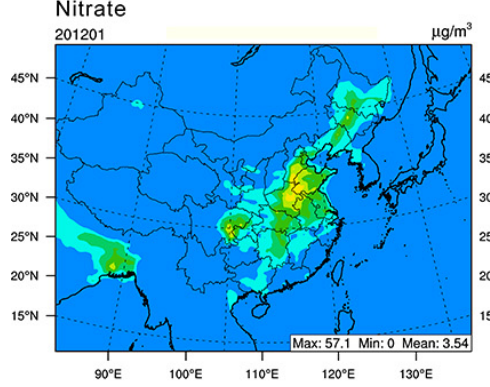

2013Met

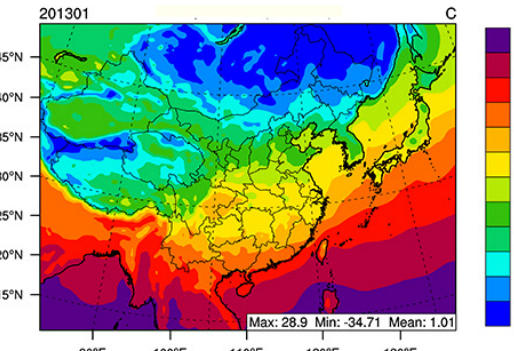

${ }_{90}^{\circ} \mathrm{E} \quad 100^{\circ} \mathrm{E} \quad 110^{\circ} \mathrm{E} \quad{ }^{120^{\circ} \mathrm{E}} \quad 130^{\circ} \mathrm{E}$

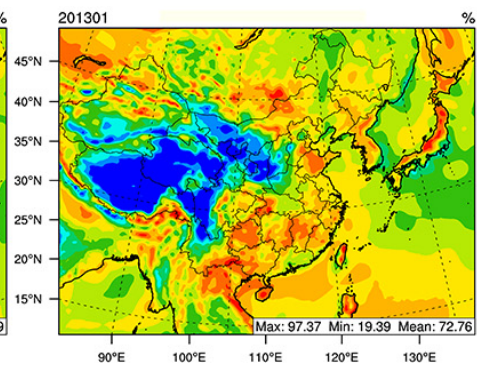

$\begin{array}{lllll}90^{\circ} \mathrm{E} & 100^{\circ} \mathrm{E} & 110^{\circ} \mathrm{E} & 120^{\circ} \mathrm{E} & 130^{\circ} \mathrm{E}\end{array}$

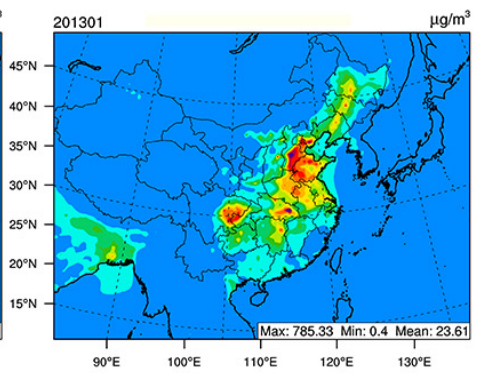

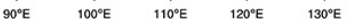

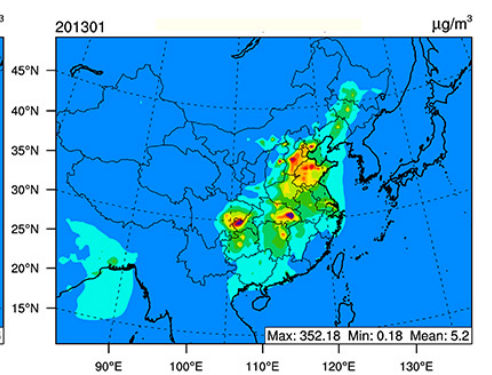

$\begin{array}{lllll}90^{\circ} \mathrm{E} & 100^{\circ} \mathrm{E} & 110^{\circ} \mathrm{E} & 120^{\circ} \mathrm{E} & 130^{\circ} \mathrm{E}\end{array}$

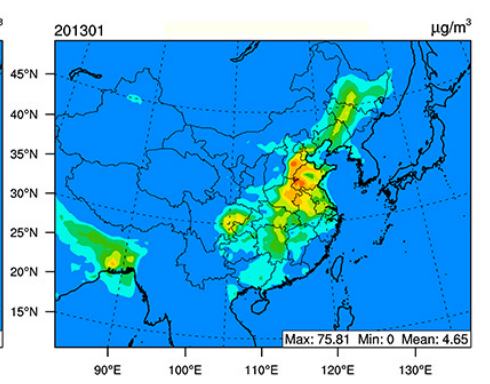

2013Met - 2012Met
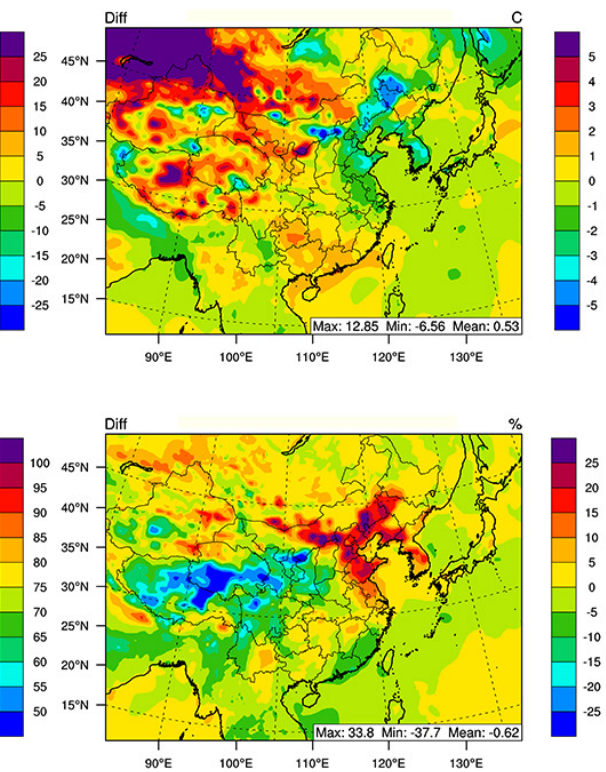

$\begin{array}{lllll}90^{\circ} \mathrm{E} & 100^{\circ} \mathrm{E} & 110^{\circ} \mathrm{E} & 120^{\circ} \mathrm{E} & 130^{\circ} \mathrm{E}\end{array}$
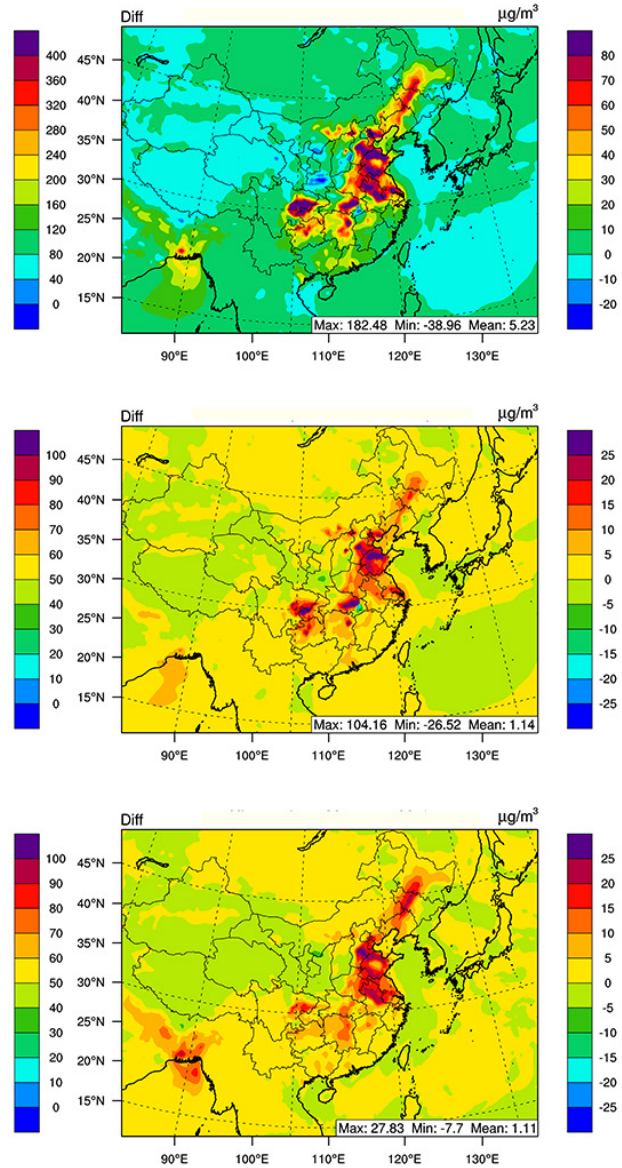

Figure 8. Spatial distributions of the monthly (January 2013) mean temperature, RH and concentrations of PM 2.5 , sulfate and nitrate simulated by the revised CMAQ model with meteorological fields of 2012 (left) and 2013 (middle), and the differences between these two simulations (right). 
Table 8. Domain-wide performance statistics of the original and revised CMAQ.

\begin{tabular}{llrrrrrrrrr}
\hline & \multicolumn{3}{c}{$\mathrm{CO}^{\mathrm{a}}$} & \multicolumn{2}{c}{$\mathrm{NO}_{2}^{\mathrm{a}}$} & \multicolumn{2}{c}{$\mathrm{SO}_{2}^{\mathrm{a}}$} & & $\mathrm{PM}_{2.5}^{\mathrm{a}}$ & \multicolumn{2}{c}{$\mathrm{PM}_{10}^{\mathrm{a}}$} \\
\hline & Original & Revised & Original & Revised & Original & Revised & Original & Revised & Original & Revised \\
\hline Data pairs & 9338 & 9338 & 9366 & 9366 & 9384 & 9384 & 9335 & 9335 & 9143 & 9143 \\
MeanObs & 2.3 & 2.3 & 66.9 & 66.9 & 86.7 & 86.7 & 142.9 & 142.9 & 202.2 & 202.2 \\
MeanSim & 1.8 & 1.8 & 75.8 & 74.3 & 131.0 & 120.0 & 154.4 & 180.2 & 179.5 & 203.3 \\
$R$ & 0.5 & 0.5 & 0.5 & 0.4 & 0.4 & 0.4 & 0.6 & 0.6 & 0.6 & 0.6 \\
MB & -0.5 & -0.5 & 9.0 & 7.5 & 44.4 & 33.4 & 11.5 & 37.3 & -22.7 & 1.2 \\
RMSE & 1.5 & 1.5 & 35.3 & 34.1 & 119.1 & 110.5 & 86.9 & 111.0 & 116.1 & 122.5 \\
NMB (\%) & -20.6 & -20.5 & 13.4 & 11.2 & 51.2 & 38.5 & 8.1 & 26.1 & -11.2 & 0.6 \\
NME (\%) & 43.3 & 43.3 & 41.9 & 39.4 & 91.6 & 84.6 & 41.3 & 54.3 & 38.1 & 42.4 \\
\hline
\end{tabular}

a The units of $\mathrm{CO}, \mathrm{NO}_{2}, \mathrm{SO}_{2}, \mathrm{PM}_{2.5}$ and $\mathrm{PM}_{10}$ are $\mathrm{mg} \mathrm{m}^{-3}, \mu \mathrm{g} \mathrm{m}{ }^{-3}, \mu \mathrm{g} \mathrm{m}^{-3}, \mu \mathrm{g} \mathrm{m}^{-3}$ and $\mu \mathrm{g} \mathrm{m}^{-3}$, respectively.

sumed for those reactions and the gas uptake coefficients are assumed to be linearly correlated with RH. Those simplified treatments neglect the effects of complex aerosol compositions and surface uptake, diffusion, and coating and reaction processes, which could inevitably introduce errors and uncertainties in this work (Wei, 2010). As a consequence, for example, while the peak concentrations of sulfate and nitrate during the haze pollution event were sharp and occurred during a narrow time window, the revised CMAQ predicts lower and wider spread concentrations. The RH-dependent parameterization of uptake coefficients derived in this work can be refined to consider additional factors, such as temperature, aerosol compositions, amounts of metal catalyst and surface conditions. In addition, some newly reported heterogeneous reactions, such as $\mathrm{SO}_{2}$ oxidation promoted by $\mathrm{NO}_{\mathrm{x}}$ (He et al., 2014) and $\mathrm{OH}$ derived from heterogeneous $\mathrm{ClNO}_{2}$ production (Sarwar et al., 2014), can enhance SNA but have not yet been included in this work, but should be incorporated into CMAQ in the future.

Second, there is a lack of sufficient site-specific hourly data for $\mathrm{PM}_{2.5}$ and its composition, which are crucial to the model evaluation and improvement. For example, we do not have observation data to evaluate the predicted $\mathrm{Fe}$ and $\mathrm{Mn}$ in aerosols. The underprediction of $\mathrm{Fe}$ and $\mathrm{Mn}$ can contribute to the underprediction of sulfate, because the metal catalysis pathway is important for sulfate formation. Although this might not be a critical issue as the model can well predict sulfate concentration in clean days, more observed data for compositions of $\mathrm{PM}_{2.5}$ are needed to comprehensively evaluate the model.

Finally, the WRF/CMAQ system used in this work is not online-coupled, which does not account for the feedbacks of chemistry and aerosol into meteorology. Wang et al. (2014a) simulated the same episode using the online-coupled CMAQ and found that including aerosol feedback can increase total aerosol loadings during haze conditions and improve model performance, but can lead to larger enhancement of primary aerosols than secondary aerosols, which is opposite to the observations. Online-coupled models with improved chem- istry should be developed in the future. Addressing these uncertainties requires an integration of field studies, laboratory experiments and modeling work by the entire community.

\section{The Supplement related to this article is available online at doi:10.5194/acp-15-2031-2015-supplement.}

Acknowledgements. This work was supported by China's National Basic Research Program (2010CB951803 and 2014CB441301), the National Science Foundation of China (41222036 and 21221004), the Japan International Cooperation Agency, and the US DOE climate modeling programs (DESC0006695) at NCSU, USA. We thank the constructive comments from Dr. Muller and two anonymous reviewers.

Edited by: H. Su

\section{References}

American Lung Association: 2005 research highlights: health effects of particulate matter and ozone air pollution, http://www. northeastdiesel.org/pdf/ALA-05-health-studies-biblio.pdf (last access: June 2014), 2006.

Bey, I., Jacob, D. J., Yantosca, R. M., Logan, J. A., Field, B. D., Fiore, A. M., Li, Q., Liu, H. Y., Mickley, L. J., and Schultz, M. G.: Global modeling of tropospheric chemistry with assimilated meteorology: Model description and evaluation, J. Geophys. Res.-Atmos., 106, 23073-23095, doi:10.1029/2001jd000807, 2001.

Chang, J. S., Brost, R. A., Isaksen, I. S. A., Madronich, S., Middleton, P., Stockwell, W. R., and Walcek, C. J.: A threedimensional Eulerian acid deposition model: Physical concepts and formulation, J. Geophys. Res.-Atmos., 92, 14681-14700, doi:10.1029/JD092iD12p14681, 1987.

Chang, W. L., Bhave, P. V., Brown, S. S., Riemer, N., Stutz, J., and Dabdub, D.: Heterogeneous Atmospheric 
Chemistry, Ambient Measurements, and Model Calculations of $\mathrm{N}_{2} \mathrm{O}_{5}$ : A Review, Aerosol. Sci. Tech., 45, 665-695, doi:10.1080/02786826.2010.551672, 2011.

Chou, M.-D., Suarez, M. J., Ho, C.-H., Yan, M. M. H., and Lee, K.-T.: Parameterizations for Cloud Overlapping and Shortwave Single-Scattering Properties for Use in General Circulation and Cloud Ensemble Models, J. Climate, 11, 202-214, doi:10.1175/1520-0442(1998)011<0202:pfcoas>2.0.co;2, 1998.

Crowley, J. N., Ammann, M., Cox, R. A., Hynes, R. G., Jenkin, M. E., Mellouki, A., Rossi, M. J., Troe, J., and Wallington, T. J.: Evaluated kinetic and photochemical data for atmospheric chemistry: Volume V - heterogeneous reactions on solid substrates, Atmos. Chem. Phys., 10, 9059-9223, doi:10.5194/acp-10-90592010, 2010.

Dentener, F. J., Carmichael, G. R., Zhang, Y., Lelieveld, J., and Crutzen, P. J.: Role of mineral aerosol as a reactive surface in the global troposphere, J. Geophys. Res.-Atmos., 101, 2286922889, doi:10.1029/96jd01818, 1996.

Ding, Y. H., and Liu, Y. J.: Analysis of long-term variations of fog and haze in China in recent 50 years and their relations with atmospheric humidity, Sci. China-Earth Sci., 57, 36-46, doi:10.1007/s11430-013-4792-1, 2014.

Fountoukis, C. and Nenes, A.: ISORROPIA II: a computationally efficient thermodynamic equilibrium model for $\mathrm{K}^{+}-\mathrm{Ca}^{2+}-$ $\mathrm{Mg}^{2+}-\mathrm{NH}_{4}^{+}-\mathrm{Na}^{+}-\mathrm{SO}_{4}^{2-}-\mathrm{NO}_{3}^{-}-\mathrm{Cl}^{-}-\mathrm{H}_{2} \mathrm{O}$ aerosols, Atmos. Chem. Phys., 7, 4639-4659, doi:10.5194/acp-7-4639-2007, 2007.

Fu, X., Wang, S. X., Cheng, Z., Xing, J., Zhao, B., Wang, J. D., and Hao, J. M.: Source, transport and impacts of a heavy dust event in the Yangtze River Delta, China, in 2011, Atmos. Chem. Phys., 14, 1239-1254, doi:10.5194/acp-14-1239-2014, 2014.

Gong, S. L.: A parameterization of sea-salt aerosol source function for sub- and super-micron particles, Global Biogeochem. Cy., 17, 1097, doi:10.1029/2003gb002079, 2003.

Guenther, A. B., Jiang, X., Heald, C. L., Sakulyanontvittaya, T., Duhl, T., Emmons, L. K., and Wang, X.: The Model of Emissions of Gases and Aerosols from Nature version 2.1 (MEGAN2.1): an extended and updated framework for modeling biogenic emissions, Geosci. Model Dev., 5, 1471-1492, doi:10.5194/gmd-51471-2012, 2012.

He, H., Wang, Y., Ma, Q., Ma, J., Chu, B., Ji, D., Tang, G., Liu, C., Zhang, H., and Hao, J.: Mineral dust and $\mathrm{NO}_{\mathrm{x}}$ promote the conversion of $\mathrm{SO}_{2}$ to sulfate in heavy pollution days, Sci. Rep., 4, 4172, doi:10.1038/srep04172, 2014.

Henson, B. F., Wilson, K. R., and Robinson, J. M.: A physical adsorption model of the dependence of $\mathrm{ClONO}_{2}$ heterogeneous reactions on relative humidity, Geophys. Res. Lett., 23, 10211024, doi:10.1029/96g100871, 1996.

Hong, S. Y. and Lim, J. O. J.: The WRF Single-Moment 6-Class Microphysics Scheme (WSM6), J. Korean Meteor. Soc., 42, 129151, http://www2.mmm.ucar.edu/wrf/users/docs/WSM6-hong_ and_lim_JKMS.pdf (last access: June 2014), 2006.

Jacob, D. J.: Heterogeneous chemistry and tropospheric ozone, Atmos. Environ., 34, 2131-2159, doi:10.1016/S13522310(99)00462-8, 2000.

Ji, D., Li, L., Wang, Y., Zhang, J., Cheng, M., Sun, Y., Liu, Z., Wang, L., Tang, G., Hu, B., Chao, N., Wen, T., and Miao, H.: The heaviest particulate air-pollution episodes occurred in northern China in January, 2013: Insights gained from observation, Atmos. Environ., 92, 546-556, doi:10.1016/j.atmosenv.2014.04.048, 2014.

Kain, J. S.: The Kain-Fritsch Convective Parameterization: An Update, J. Appl. Meteorol., 43, 170-181, doi:10.1175/15200450(2004)043<0170:tkcpau>2.0.co;2, 2004.

Kolb, C. E., Cox, R. A., Abbatt, J. P. D., Ammann, M., Davis, E. J., Donaldson, D. J., Garrett, B. C., George, C., Griffiths, P. T., Hanson, D. R., Kulmala, M., McFiggans, G., Pöschl, U., Riipinen, I., Rossi, M. J., Rudich, Y., Wagner, P. E., Winkler, P. M., Worsnop, D. R., and O' Dowd, C. D.: An overview of current issues in the uptake of atmospheric trace gases by aerosols and clouds, Atmos. Chem. Phys., 10, 10561-10605, doi:10.5194/acp-10-10561-2010, 2010.

Lammel, G. and Leip, A.: Formation of Nitrate and Sulfate in the Plume of Berlin, Environ. Sci. Pollut. R., 12, 213-220, doi:10.1065/espr2005.03.240, 2005.

Lei, Y., Zhang, Q., He, K. B., and Streets, D. G.: Primary anthropogenic aerosol emission trends for China, 1990-2005, Atmos. Chem. Phys., 11, 931-954, doi:10.5194/acp-11-931-2011, 2011a.

Lei, Y., Zhang, Q., Nielsen, C., and He, K.: An inventory of primary air pollutants and $\mathrm{CO}_{2}$ emissions from cement production in China, 1990-2020, Atmos. Environ., 45, 147-154, doi:10.1016/j.atmosenv.2010.09.034, 2011b.

Li, M., Zhang, Q., Streets, D. G., He, K. B., Cheng, Y. F., Emmons, L. K., Huo, H., Kang, S. C., Lu, Z., Shao, M., Su, H., Yu, X., and Zhang, Y.: Mapping Asian anthropogenic emissions of nonmethane volatile organic compounds to multiple chemical mechanisms, Atmos. Chem. Phys., 14, 5617-5638, doi:10.5194/acp14-5617-2014, 2014.

Li, W., and Shao, L.: Transmission electron microscopy study of aerosol particles from the brown hazes in northern China, J. Geophys. Res.-Atmos., 114, D09302, doi:10.1029/2008jd011285, 2009.

Li, W., and Shao, L.: Characterization of mineral particles in winter fog of Beijing analyzed by TEM and SEM, Environ. Monit. Assess., 161, 565-573, doi:10.1007/s10661-009-0768-1, 2010.

Li, W., Zhou, S., Wang, X., Xu, Z., Yuan, C., Yu, Y., Zhang, Q., and Wang, W.: Integrated evaluation of aerosols from regional brown hazes over northern China in winter: Concentrations, sources, transformation, and mixing states, J. Geophys. Res.-Atmos., 116, D09301, doi:10.1029/2010jd015099, 2011.

Li, Z., Xia, X., Cribb, M., Mi, W., Holben, B., Wang, P., Chen, H., Tsay, S.-C., Eck, T. F., Zhao, F., Dutton, E. G., and Dickerson, R. E.: Aerosol optical properties and their radiative effects in northern China, J. Geophys. Res.-Atmos., 112, D22S01, doi:10.1029/2006jd007382, 2007.

Liu, Y., Gibson, E. R., Cain, J. P., Wang, H., Grassian, V. H., and Laskin, A.: Understanding of regional air pollution over China using CMAQ, part I performance evaluation and seasonal variation, Atmos. Environ., 44, 2415-2426, doi:10.1016/j.atmosenv.2010.03.035, 2010.

Liu, Y., Gibson, Cain, Wang, H., Grassian, and Laskin, A.: Kinetics of Heterogeneous Reaction of $\mathrm{CaCO}_{3}$ Particles with Gaseous $\mathrm{HNO}_{3}$ over a Wide Range of Humidity, J. Phys. Chem. A, 112, 1561-1571, doi:10.1021/jp076169h, 2008.

Mass, C. and Ovens, D.: WRF model physics: progress, problems, and perhaps some solutions, in: The 11th WRF Users' Workshop, 21-25 June, NCAR Center Green Cam- 
pus, http://www.mmm.ucar.edu/wrf/users/workshops/WS2010/ presentations/session (last access: June 2014), 2010.

McNaughton, C. S., Clarke, A. D., Kapustin, V., Shinozuka, Y., Howell, S. G., Anderson, B. E., Winstead, E., Dibb, J., Scheuer, E., Cohen, R. C., Wooldridge, P., Perring, A., Huey, L. G., Kim, S., Jimenez, J. L., Dunlea, E. J., DeCarlo, P. F., Wennberg, P. O., Crounse, J. D., Weinheimer, A. J., and Flocke, F.: Observations of heterogeneous reactions between Asian pollution and mineral dust over the Eastern North Pacific during INTEX-B, Atmos. Chem. Phys., 9, 8283-8308, doi:10.5194/acp-9-8283-2009, 2009

Mercado, L. M., Bellouin, N., Sitch, S., Boucher, O., Huntingford, C., Wild, M., and Cox, P. M.: Impact of changes in diffuse radiation on the global land carbon sink, Nature, 458, 1014-1017, doi:10.1038/nature07949, 2009.

Mlawer, E. J., Taubman, S. J., Brown, P. D., Iacono, M. J., and Clough, S. A.: Radiative transfer for inhomogeneous atmospheres: RRTM, a validated correlated-k model for the longwave, J. Geophys. Res.-Atmos., 102, 16663-16682, doi:10.1029/97jd00237, 1997.

Mogili, P. K., Kleiber, P. D., Young, M. A., and Grassian, V. H.: $\mathrm{N}_{2} \mathrm{O}_{5}$ hydrolysis on the components of mineral dust and sea salt aerosol: Comparison study in an environmental aerosol reaction chamber, Atmos. Environ., 40, 7401-7408, doi:10.1016/j.atmosenv.2006.06.048, 2006.

National Bureau of Statistics: China Statistical Yearbook 2013, China Statistics Press, Beijing, 2013.

Peckhaus, A., Grass, S., Treuel, L., and Zellner, R.: Deliquescence and Efflorescence Behavior of Ternary Inorganic/Organic/Water Aerosol Particles, J. Phys. Chem. A, 116, 6199-6210, doi:10.1021/jp211522t, 2012.

Pleim, J. E.: A Combined Local and Nonlocal Closure Model for the Atmospheric Boundary Layer. Part I: Model Description and Testing, J. Appl. Meteorol. Clim., 46, 1383-1395, doi:10.1175/jam2539.1, 2007.

Quan, J., Tie, X., Zhang, Q., Liu, Q., Li, X., Gao, Y., and Zhao, D.: Characteristics of heavy aerosol pollution during the 20122013 winter in Beijing, China, Atmos. Environ., 88, 83-89, doi:10.1016/j.atmosenv.2014.01.058, 2014.

Ravishankara, A. R.: Heterogeneous and Multiphase Chemistry in the Troposphere, Science, 276, 1058-1065, doi:10.1126/science.276.5315.1058, 1997.

Reid, J. P. and Sayer, R. M.: Heterogeneous atmospheric aerosol chemistry: laboratory studies of chemistry on water droplets, Chem. Soc. Rev., 32, 70-79, doi:10.1039/b204463n, 2003.

Sarwar, G., Simon, H., Xing, J., and Mathur, R.: Importance of tropospheric $\mathrm{ClNO}_{2}$ chemistry across the Northern Hemisphere, Geophys. Res. Lett., 41, 4050-4058, doi:10.1002/2014GL059962, 2014.

Schumann, U. and Huntrieser, H.: The global lightning-induced nitrogen oxides source, Atmos. Chem. Phys., 7, 3823-3907, doi:10.5194/acp-7-3823-2007, 2007.

Seinfeld, J. H., Carmichael, G. R., Arimoto, R., Conant, W. C., Brechtel, F. J., Bates, T. S., Cahill, T. A., Clarke, A. D., Doherty, S. J., Flatau, P. J., Huebert, B. J., Kim, J., Markowicz, K. M., Quinn, P. K., Russell, L. M., Russell, P. B., Shimizu, A., Shinozuka, Y., Song, C. H., Tang, Y., Uno, I., Vogelmann, A. M., Weber, R. J., Woo, J.-H., and Zhang, X. Y.: ACEASIA: Regional Climatic and Atmospheric Chemical Effects of
Asian Dust and Pollution, B. Am. Meteorol. Soc., 85, 367-380, doi:10.1175/bams-85-3-367, 2004.

Shang, J., Li, J., and Zhu, T.: Heterogeneous reaction of $\mathrm{SO}_{2}$ on $\mathrm{TiO}_{2}$ particles, Sci. China Chem., 53, 2637-2643, doi:10.1007/s11426-010-4160-3, 2010.

Song, C. H. and Carmichael, G. R.: A three-dimensional modeling investigation of the evolution processes of dust and sea-salt particles in east Asia, J. Geophys. Res.-Atmos., 106, 18131-18154, doi:10.1029/2000jd900352, 2001.

Stutz, J., Alicke, B., Ackermann, R., Geyer, A., Wang, S., White, A. B., Williams, E. J., Spicer, C. W., and Fast, J. D.: Relative humidity dependence of HONO chemistry in urban areas, J. Geophys. Res.-Atmos., 109, D03307, doi:10.1029/2003jd004135, 2004.

Sun, Y., Zhuang, G., Tang, A., Wang, Y., and An, Z.: Chemical Characteristics of $\mathrm{PM}_{2.5}$ and $\mathrm{PM}_{10}$ in Haze-Fog Episodes in Beijing, Environ. Sci. Technol., 40, 3148-3155, doi:10.1021/es051533g, 2006.

Sun, Y., Wang, Z., Fu, P., Jiang, Q., Yang, T., Li, J., and Ge, X.: The impact of relative humidity on aerosol composition and evolution processes during wintertime in Beijing, China, Atmos. Environ., 77, 927-934, doi:10.1016/j.atmosenv.2013.06.019, 2013.

Sun, Y., Jiang, Q., Wang, Z., Fu, P., Li, J., Yang, T., and Yin, Y.: Investigation of the Sources and Evolution Processes of Severe Haze Pollution in Beijing in January 2013, J. Geophys. Res.Atmos., 119, 4380-4398, doi:10.1002/2014jd021641, 2014.

Usher, C. R., Michel, A. E., and Grassian, V. H.: Reactions on Mineral Dust, Chem. Rev., 103, 4883-4940, doi:10.1021/cr020657y, 2003.

Walcek, C. J., and Taylor, G. R.: A Theoretical Method for Computing Vertical Distributions of Acidity and Sulfate Production within Cumulus Clouds, J. Atmos. Sci., 43, 339-355, doi:10.1175/1520-0469(1986)043<0339:atmfcv>2.0.co;2, 1986.

Wang, L. T., Jang, C., Zhang, Y., Wang, K., Zhang, Q., Streets, D., Fu, J., Lei, Y., Schreifels, J., He, K., Hao, J., Lam, Y.-F., Lin, J., Meskhidze, N., Voorhees, S., Evarts, D., and Phillips, S.: Assessment of air quality benefits from national air pollution control policies in China. Part I: Background, emission scenarios and evaluation of meteorological predictions, Atmos. Environ., 44, 3442-3448, doi:10.1016/j.atmosenv.2010.05.051, 2010.

Wang, K., Zhang, Y., Nenes, A., and Fountoukis, C.: Implementation of dust emission and chemistry into the Community Multiscale Air Quality modeling system and initial application to an Asian dust storm episode, Atmos. Chem. Phys., 12, 1020910237, doi:10.5194/acp-12-10209-2012, 2012a.

Wang, S. W., Zhang, Q., Streets, D. G., He, K. B., Martin, R. V., Lamsal, L. N., Chen, D., Lei, Y., and Lu, Z.: Growth in NOx emissions from power plants in China: bottom-up estimates and satellite observations, Atmos. Chem. Phys., 12, 4429-4447, doi:10.5194/acp-12-4429-2012, 2012 b.

Wang, X., Wang, W., Yang, L., Gao, X., Nie, W., Yu, Y., Xu, P., Zhou, Y., and Wang, Z.: The secondary formation of inorganic aerosols in the droplet mode through heterogeneous aqueous reactions under haze conditions, Atmos. Environ., 63, 68-76, doi:10.1016/j.atmosenv.2012.09.029, 2012c.

Wang, J., Wang, S., Jiang, J., Ding, A., Zheng, M., Zhao, B., Wong, D. C., Zhou, W., Zheng, G., Wang, L., Pleim, J. E., and Hao, J.: Impact of aerosol-meteorology interactions on fine particle pollution during China's severe haze episode in January 2013, Environ. Res. Lett., 9, doi:10.1088/1748-9326/9/9/094002, 2014a. 
Wang, L. T., Wei, Z., Yang, J., Zhang, Y., Zhang, F. F., Su, J., Meng, C. C., and Zhang, Q.: The 2013 severe haze over southern Hebei, China: model evaluation, source apportionment, and policy implications, Atmos. Chem. Phys., 14, 3151-3173, doi:10.5194/acp-14-3151-2014, 2014b.

Wang, Y. S., Yao, L., Wang, L. L., Liu, Z. R., Ji, D. S., Tang, G. Q., Zhang, J. K., Sun, Y., Hu, B., and Xin, J. Y.: Mechanism for the formation of the January 2013 heavy haze pollution episode over central and eastern China, Sci. China-Earth Sci., 57, 14-25, doi:10.1007/s11430-013-4773-4, 2014c.

Wang, Z. F., Li, J., Wang, Z., Yang, W. Y., Tang, X., Ge, B. Z., Yan, P. Z., Zhu, L. L., Chen, X. S., Chen, H. S., Wang, W., Li, J. J., Liu, B., Wang, X. Y., Wand, W., Zhao, Y. L., Lu, N., and $\mathrm{Su}, \mathrm{D}$. B.: Modeling study of regional severe hazes over mid-eastern China in January 2013 and its implications on pollution prevention and control, Sci. China-Earth Sci., 57, 3-13, doi:10.1007/s11430-013-4793-0, 2014d.

Wang, S., Xing, J., Jang, C., Zhu, Y., Fu, J. S., and Hao, J.: Impact Assessment of Ammonia Emissions on Inorganic Aerosols in East China Using Response Surface Modeling Technique, Environ. Sci. Technol., 45, 9293-9300, doi:10.1021/es2022347, 2011.

Wang, Y., Zhuang, G., Sun, Y., and An, Z.: The variation of characteristics and formation mechanisms of aerosols in dust, haze, and clear days in Beijing, Atmos. Environ., 40, 6579-6591, doi:10.1016/j.atmosenv.2006.05.066, 2006.

Wei, C.: Modeling the effects of heterogeneous reactions on atmospheric chemistry and aerosol properties, PhD Diss., University of Iowa, http://ir.uiowa.edu/etd/903 (last access: June 2014), 2010.

Whitten, G. Z., Heo, G., Kimura, Y., McDonald-Buller, E., Allen, D. T., Carter, W. P. L., and Yarwood, G.: A new condensed toluene mechanism for Carbon Bond: CB05-TU, Atmos. Environ., 44, 5346-5355, doi:10.1016/j.atmosenv.2009.12.029, 2010.

Wu, L. Y., Tong, S. R., Wang, W. G., and Ge, M. F.: Effects of temperature on the heterogeneous oxidation of sulfur dioxide by ozone on calcium carbonate, Atmos. Chem. Phys., 11, 65936605, doi:10.5194/acp-11-6593-2011, 2011.

Xiu, A. and Pleim, J. E.: Development of a Land Surface Model. Part I: Application in a Mesoscale Meteorological Model, J. Appl. Meteorol., 40, 192-209, doi:10.1175/15200450(2001)040<0192:doalsm>2.0.co;2, 2001.

Yang, F., Tan, J., Zhao, Q., Du, Z., He, K., Ma, Y., Duan, F., and Chen, G.: Characteristics of $\mathrm{PM}_{2.5}$ speciation in representative megacities and across China, Atmos. Chem. Phys., 11, 52075219, doi:10.5194/acp-11-5207-2011, 2011.

Yang, K., Dickerson, R. R., Carn, S. A., Ge, C., and Wang, J.: First observations of $\mathrm{SO}_{2}$ from the satellite Suomi NPP OMPS: Widespread air pollution events over China, Geophys. Res. Lett., 40, 4957-4962, doi:10.1002/grl.50952, 2013.

Zhang, Y., Sunwoo, Y., Kotamarthi, V., and Carmichael, G. R.: Photochemical Oxidant Processes in the Presence of Dust: An Evaluation of the Impact of Dust on Particulate Nitrate and Ozone Formation, J. Appl. Meteorol., 33, 813-824, doi:10.1175/15200450(1994)033<0813:popitp>2.0.co;2, 1994.

Zhang, Y. and Carmichael, G. R.: The Role of Mineral Aerosol in Tropospheric Chemistry in East Asia-A Model Study, J. Appl. Meteorol., 38, 353-366, doi:10.1175/15200450(1999)038<0353:tromai>2.0.co;2, 1999.
Zhang, Y., Liu, P., Pun, B., and Seigneur, C.: A comprehensive performance evaluation of MM5-CMAQ for the Summer 1999 Southern Oxidants Study episode - Part I: Evaluation protocols, databases, and meteorological predictions, Atmos. Environ., 40, 4825-4838, doi:10.1016/j.atmosenv.2005.12.043, 2006.

Zhang, Q., Streets, D. G., He, K., Wang, Y., Richter, A., Burrows, J. P., Uno, I., Jang, C. J., Chen, D., Yao, Z., and Lei, Y.: $\mathrm{NO}_{\mathrm{x}}$ emission trends for China, 1995-2004: The view from the ground and the view from space, J. Geophys. Res.-Atmos., 112, D22306, doi:10.1029/2007jd008684, 2007.

Zhang, Q., Streets, D. G., Carmichael, G. R., He, K. B., Huo, H., Kannari, A., Klimont, Z., Park, I. S., Reddy, S., Fu, J. S., Chen, D., Duan, L., Lei, Y., Wang, L. T., and Yao, Z. L.: Asian emissions in 2006 for the NASA INTEX-B mission, Atmos. Chem. Phys., 9, 5131-5153, doi:10.5194/acp-9-5131-2009, 2009.

Zhang, Y., Cheng, S.-H., Chen, Y.-S., and Wang, W.-X.: Application of MM5 in China: Model evaluation, seasonal variations, and sensitivity to horizontal grid resolutions, Atmos. Environ., 45, 3454-3465, doi:10.1016/j.atmosenv.2011.03.019, 2011.

Zhang, Y., Chen, Y., Sarwar, G., and Schere, K.: Impact of gasphase mechanisms on Weather Research Forecasting Model with Chemistry (WRF/Chem) predictions: Mechanism implementation and comparative evaluation, J. Geophys. Res.-Atmos., 117, D01301, doi:10.1029/2011jd015775, 2012.

Zhang, J. K., Sun, Y., Liu, Z. R., Ji, D. S., Hu, B., Liu, Q., and Wang, Y. S.: Characterization of submicron aerosols during a month of serious pollution in Beijing, 2013, Atmos. Chem. Phys., 14, 2887-2903, doi:10.5194/acp-14-2887-2014, 2014a.

Zhang, R. H., Li, Q., and Zhang, R. N.: Meteorological conditions for the persistent severe fog and haze event over eastern China in January 2013, Sci. China-Earth Sci., 57, 26-35, doi:10.1007/s11430-013-4774-3, 2014b.

Zhao, Y., Duan, L., Xing, J., Larssen, T., Nielsen, C. P., and Hao, J.: Soil Acidification in China: Is Controlling $\mathrm{SO}_{2}$ Emissions Enough?, Environ. Sci. Technol., 43, 8021-8026, doi:10.1021/es901430n, 2009.

Zhao, P., Zhang, X., Xu, X., and Zhao, X.: Long-term visibility trends and characteristics in the region of Beijing, Tianjin, and Hebei, China, Atmos. Res., 101, 711-718, doi:10.1016/j.atmosres.2011.04.019, 2011.

Zhao, B., Wang, S., Wang, J., Fu, J. S., Liu, T., Xu, J., Fu, X., and Hao, J.: Impact of national $\mathrm{NO}_{\mathrm{x}}$ and $\mathrm{SO}_{2}$ control policies on particulate matter pollution in China, Atmos. Environ., 77, 453-463, doi:10.1016/j.atmosenv.2013.05.012, 2013a.

Zhao, X. J., Zhao, P. S., Xu, J., Meng, W., Pu, W. W., Dong, F., He, D., and Shi, Q. F.: Analysis of a winter regional haze event and its formation mechanism in the North China Plain, Atmos. Chem. Phys., 13, 5685-5696, doi:10.5194/acp-13-5685-2013, 2013b.

Zheng, B., Huo, H., Zhang, Q., Yao, Z. L., Wang, X. T., Yang, X. F., Liu, H., and He, K. B.: High-resolution mapping of vehicle emissions in China in 2008, Atmos. Chem. Phys., 14, 9787-9805, doi:10.5194/acp-14-9787-2014, 2014a.

Zheng, G. J., Duan, F. K., Ma, Y. L., Cheng, Y., Zheng, B., Zhang, Q., Huang, T., Kimoto, T., Chang, D., Su, H., Pöschl, U., Cheng, Y. F., and He, K. B.: Exploring the severe winter haze in Beijing, Atmos. Chem. Phys. Discuss., 14, 17907-17942, doi:10.5194/acpd-14-17907-2014, 2014b. 